\title{
KLÁŠTER ŘÁDU NEJSVĚTĚJŠÍ TROJICE NA VYKUPOVÁNÍ OTROKŮ V ZAŠOVÉ
}

\author{
SAMUEL ŠPANIHEL - JAN MATYÁŠ - JAN ŠTĚTINA - KAMILA VALOUŠKOVÁ - \\ ZDENĚK HAVLÍČEK - LUCIE LANGOVÁ - IVANA NOVOTNÁ
}

\begin{abstract}
Abstrakt: Trinitářský klášter v Zašové je jedním z mála klášterů tohoto řádu na území České republiky. Během své krátké existence (1725-1783) rádovi bratři nejenže působili jako obnovitelé katolické viry na převážně evangelickém severním Valašsku, ale přinesli i několik inovací zejména vemédělství a důležitá byla také jejich aktivita při budováni poutniho významu obce. Od roku 2016 probihají v klášteře rekonstrukční práce, během kterých byl vykonán stavebně-historický průzkum a archeologický výzkum rajského dvora. Ziskané poznatky jou prezentovány v tomto príspěvku.
\end{abstract}

Klíčová slova: trinitáři - klášter - keramika - sklo - osteologický materiál.

\section{The Monastery of the Order of the Most Holy Trinity and Captives in Zašová}

Abstract: The Trinitarian monastery in Zašová is one of a few monasteries of this order in the Czech Republic. In the course of its short existence (1725-1783), the Trinitarians took part in the restoration of the Catholic faith in the predominantly Protestant region of northern Wallachia, and they also introduced several innovations, especially in agriculture. Their contribution to the establishment of Zašová as a pilgrimage site was no less important. The reconstruction of the monastery was launched in 2016. It involved building and historical research, as well as archaeological research into the cloister. The findings are presented in this article.

Key words: Trinitarians - monastery - pottery - glass - osteological material.

První písemná zmínka o obci Zašová (obr. 1) pochází z roku 1370, kdy je vzpomínán Choten ze Zašové, člen rodu vladyků z Krásna (Baletka 2002, 916). V Zašové stál první kostel nejpozději na počátku 80 . let 16 . století. Tehdy jím byl patrně dřevěný kostel sv. Anny (obr. 2), který měl na vížce zavěšen menší zvon z roku 1583 (Matyáš 2011, 3). Na hlavním oltáři byl umístěn milostný obraz Panny Marie, který se poprvé zmiňuje k roku 1672 - samotná malba je z 50. let 15. století. Už tehdy u něj viselo množství votivních darů, které odkazovaly na význam zdejšího kostela a zvláště mariánského obrazu. Kostelík, jejž známe jen díky vyobrazení z roku 1768 , nárokům stále častěji konaných poutí brzy nedostačoval. Potřebnost nového poutního chrámu (obr. 2) vzrostla, když i Valašsko zasáhl v letech 1714-1715 mor. Řada vesnic tehdy učinila

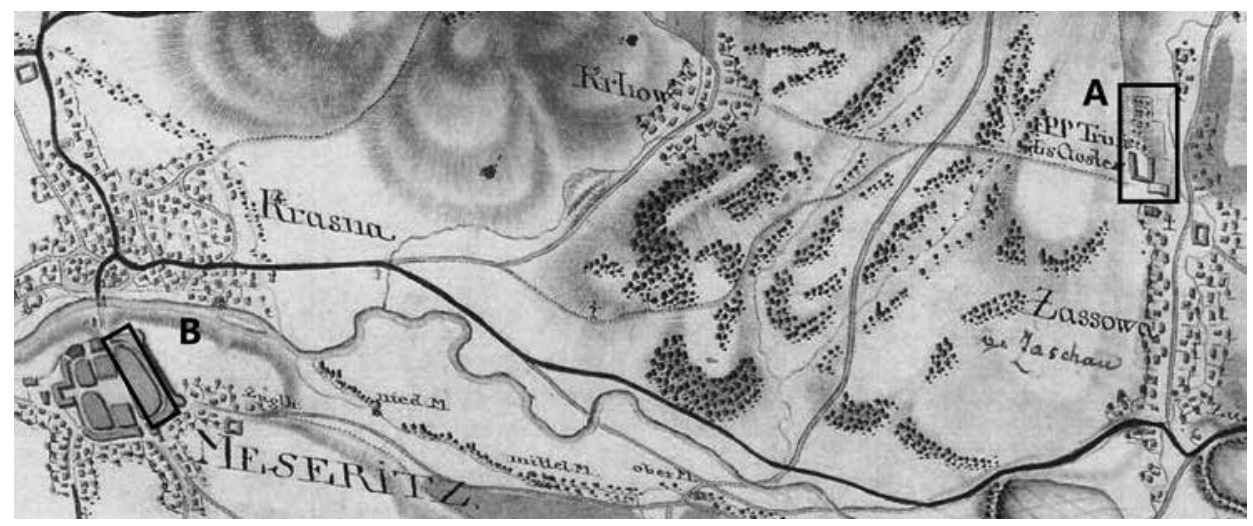

Obr. 1. Lokalizace obce Zašová na mapě I. vojenského mapování. A - poloha kláštera; B - Valašské Meziř́ičí Študlov. Zdroj https://mapire.eu/en/map/europe-18century-firstsurvey/.

Abb. 1. Lokalisierung der Gemeinde Zaschau auf einer Karte der I. Militärischen Kartierung. A - Lage des Klosters; B Valašské Meziřičí Študlov. Quelle https://mapire.eu/en/map/europe-18century-firstsurvey/. 


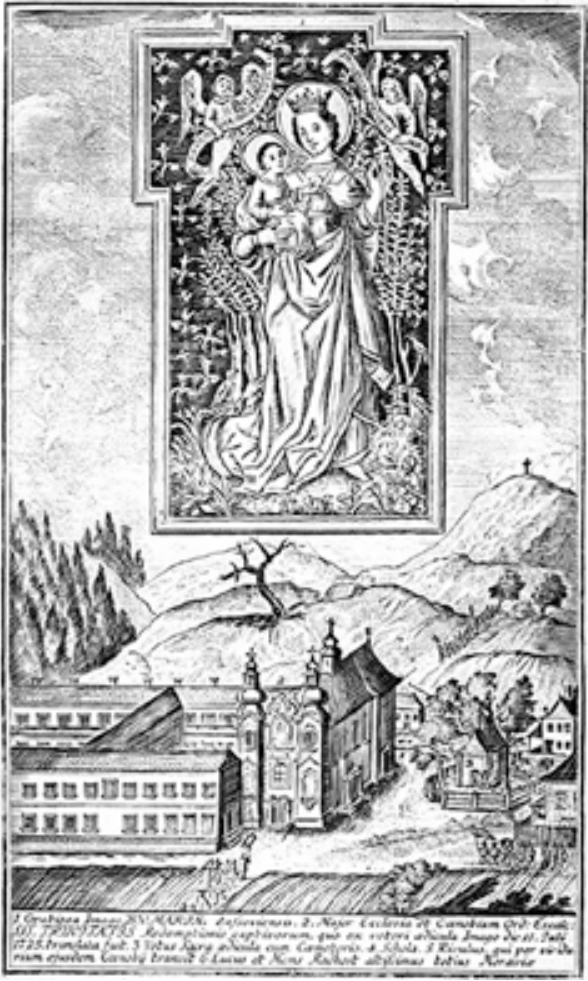

Obr. 2. Nejstarší pohled na kostel Navštívení Panny Marie a trinitářský klášter, mědiryt, Andreas a Josef Schmutzerové, 1768.

Abb. 2. Älteste Ansicht der Mariä Himmelfahrtskirche und des Trinitarierklosters, Kupferstich, Andreas und Josef Schmutzer, 1768.

zkráceně trinitáři, vznikl v samém závěru 12. století ve Francii. Zakladateli se stali Jan z Mathy a Felix z Valois. Dle pověsti měl Jan z Mathy během primice při pozdvihování vidění anděla s červenomodrým křížem na prsou, jehož doprovázeli dva otroci s těžkými řetězy. Okolo roku 1194 se Jan z Mathy seznámil s Felixem z Valois, s nímž sdílel jeho poustevnu. Jednoho dne cestou lesem oba spatř̌ili jelena s červenomodrým křížem mezi parohy. Tato událost je dostatečně motivovala $\mathrm{k}$ založení nového řádu. Janem z Mathy upravená řehole sv. Augustina se dostala až k papeži Innocenci III., který ji bulou Operante divinae dispositionis clementia 17. prosince 1198 schválil (Svátek 1990, 103). K hlavnímu poslání rádu patřilo organizování sbírek určených k vykupování křestanských otroků z muslimského zajetí. Vybrané peníze trinitáŕi dělili následovně: jedna třetina sloužila pro potřeby výkupu otroků, druhá třetina byla využita na péči o vykoupené nebo na potřebné $\mathrm{v}$ domech milosrdenství a třetí třetinou byly pokryty náklady spjaté s chodem kláštera (Buben 2007, 235, 237).

Do českých zemí se trinitářský řád rozšíríil až po vítězství nad Turky u Vídně (1683). Šlo o reformovanou větev, jejímž představitelům se říkalo španělští bosáci nebo bílí Španělé. První český trinitářský klášter byl vybudován až v roce 1708 (Buben 2007, 244; Šigut 1942, 20). V závěru 17. století se objevují také na Moravě snahy o přivedení a usazení trinitár̆ů. K nejvýraznějším postavám usilujícím o zřízení trinitářského kláštera na moravské půdě patřil fr. Václav od sv. Antonína, rodák z Krásna nad Bečvou, vlastním jménem Václav Vranečka. Fr. Václav se přibližně okolo roku 1707 svěřil se svým nápadem svému bratru Janu Bartoloměji, rektoru zašovské 
školy. Jan byl nápadem nadšen a hned mu navrhl jako vhodné místo Zašovou. K prvním mecenášům a dobrodincům, již byli nakloněni vzniku kláštera, patřil Rudolf Podstatský z Prusinovic. Podstatský slíbil věnovat $2000 \mathrm{zl}$. a jednat v otázce zřízení kláštera s hrabětem Františkem Ludvíkem ze Žerotína. Při jednáních Žerotína upozorňoval na pozitivní dopady trinitářského kláštera $\mathrm{v}$ Zašové zejména $\mathrm{v}$ oblasti posílení duchovní správy, rozvoji poutí k milostnému obrazu Panny Marie Zašovské a v boji proti tajným nekatolíkům (Matyáš 2018, 9). Žerotínovi, finančně zatíženému stavbou nového kostela, se nápad zamlouval i z pohledu hospodářského, jelikož trinitáři byli nenároční na finanční vydržování kláštera. Proto taky nakonec s uvedením trinitářů do Zašové souhlasil, přičemž se zavázal trinitářům poskytnout nezbytný stavební materiál, zahradu a roční naturální deputát z rožnovského panství (Šigut 1942, 26). Stavbu si měli po finanční stránce zajistit trinitáři sami. V dalších jednáních trinitáře zastupoval ministr pražského kláštera P. Michael od Nanebevzetí, který rovněž se Žerotínem dohodl náležitosti fundační listiny, již podepsali 22. ř́ijna 1722. Hrabě se v ní zaručil předat trinitářům rozestavěný kostel Navštívení Panny Marie s tím, že se zavázal jej dokončit včetně oltářu. Dále slíbil zajistit materiál a pozemek pro stavbu kláštera a zahradu. Roční deputát z rožnovského panství pak trinitářům zaručoval každoročně 20 měřic pšenice, 60 měřic žita, 12 měřic luštěnin, čtyři centy ryb, dva centy másla, 40 beček piva a 200 sáhů dřeva (MZA, G $10 \mathrm{Sr}, 586$ ). Nadto jim byl umožněn volný rybolov na místním potoce až po soutok s řekou Bečvou (MZA, G $10 \mathrm{Sr}, 586$ ). Fundace stanovila i povinnosti řádu vůči Žerotínovi.

S trinitáři postupně sepsali fundační listiny další dobrodinci kláštera, např́íklad Antonín Zeno z Danhausen, Jan Václav Přepiský z Richenburka či hrabě Jan Ludvík ze Žerotína na Niemodlině. Každý z uvedených daroval 2000 zl. Od vyškovského děkana Jana Václava Neupauera získali 1500 zl., uherskobrodský děkan Jan Trchalík věnoval novohorskou vinici v Lipově na strážnickém panství a manželé Oriesovi z Meziříčí „,čeli“" zahradu „Na Hrádkách“ v Krhové (Matyáš 2018, 10).

Jakmile trinitáři vyřešili fundační záležitosti se svými podporovateli, obrátili se s žádostí o povolení zřízení kláštera na církevní úrúady. V roce 1723 podal $P$. Michael od Nanebevzetí olomoucké konzistoři memoriál, v němž shrnul hlavní důvody, proč zřídit klášter v Zašové (MZA, E $65 \mathrm{TZ}$ d). Kardinál Schrattenbach v této věci přijal kladné stanovisko, což ovšem neplatilo pro úřady světské. V českých zemích platil zákaz zřizování nových mendikantských klášterů, což dvorská kancelář důsledně dodržovala (Šigut 1942, 30). O založení kláštera nakonec rozhodoval až císař Karel VI. Neustálé žádosti P. Michaela odbyl dokonce formulí „,negativam semel pro semper" (MZA, E 65 TZ c; G 10 Sr, 11; Burian 1941, 121). Až odborné zprávy výše zmíněných významných katolických hodnostářů o vhodnosti založení kláštera $\mathrm{v}$ Zašové a nízká fundační částka, z níž bylo potřeba hradit živobytí řeholníků i platy stavebních dělníků (MZA, E 65 TZ a; NA Praha, Čdk), udělaly na císaře dojem a ten pak povolil založení kláštera 24. listopadu 1724 (MZA, E 65 TZ c). Karel VI. schválil výše zmíněné fundace a nařídil jejich zápis do moravských zemských desek. V rámci schválení si vymínil několik podmínek, které byli trinitáři do budoucna nuceni dodržovat. Klášter měl mít pouze 13 řeholníků, tj. nejnižší počet pro to, aby byl z hlediska řádové organizace uznán za klášter, dále museli být jeho obyvatelé znalí moravské řeči z důvodu výuky katechismu a výpomoci ve zdejších farnostech. Trinitáři se museli nadto zavázat, že nebudou konat v zemi sbírky (MZA, E 65 TZ c). Úřední záležitosti symbolicky uzavřel 24. března $1725 \mathrm{P}$. Michael smlouvou s rožnovským farářem Bauhofferem (Matyáš 2011, 23). Na základě tohoto ujednání trinitáři převzali do své správy poutní kostel s milostným obrazem Panny Marie Zašovské.

Základní kámen kláštera byl položen 4. října 1725 za účasti Jana Matěje z Thurnu a Valsassiny jakožto světitele (Burian 1941, 124). Fundace měla být „zulänglich und genungsamb“ (NA Praha, Čdk), což trinitářům pravděpodobně působilo obtíže. Stavební materiál poskytl hrabě Žerotín. Řádoví bratří platili z darovaného kapitálu pouze dělníky, i přesto ale museli zřejmě šetřit. V dekretu s žádostí o udělení souhlasu císaře k výstavbě kláštera z 15. záŕí 1724 trinitáři doložili možnost, jak ušetřit (NA Praha, Čdk). Řeholníci, jichž mělo být zpočátku pouze pět (čtyři duchovní a jeden laik), měli vystačit s ročním deputátem z rožnovského panství dle fundační 
listiny. Ve skutečnosti to znamenalo (při dodržení všech zásad řeholního života) jíst maso pouze o nedělích a ve sváteční dny (NA Praha, Čdk). Šatstvo muselo vydržet minimálně tři roky, kabát sedm let (NA Praha, Čdk). Dodržením těchto opatření trinitáři mohli ušetřit až 570 zl. při ročním $6 \%$ úroku pro potřeby stavby kláštera (NA Praha, Čdk). Navzdory tomu se však stavba přeci jen protáhla. Začalo se nejprve východním křídlem, kterému při epištolní straně presbytáře kostela ustoupilo malé repositorium, místo nějž byla vystavěna nová a prostorná sakristie s oratoří (MZA, E 65 TZ b). Podobnou sakristii později přistavěli i na evangelijní straně presbytáře (MZA, E 65 TZ b). Toto obytné křídlo spolu s velkým sklepem dokončili v roce 1728, kdy se do něj rovněž nastěhovali. Generální kapitula

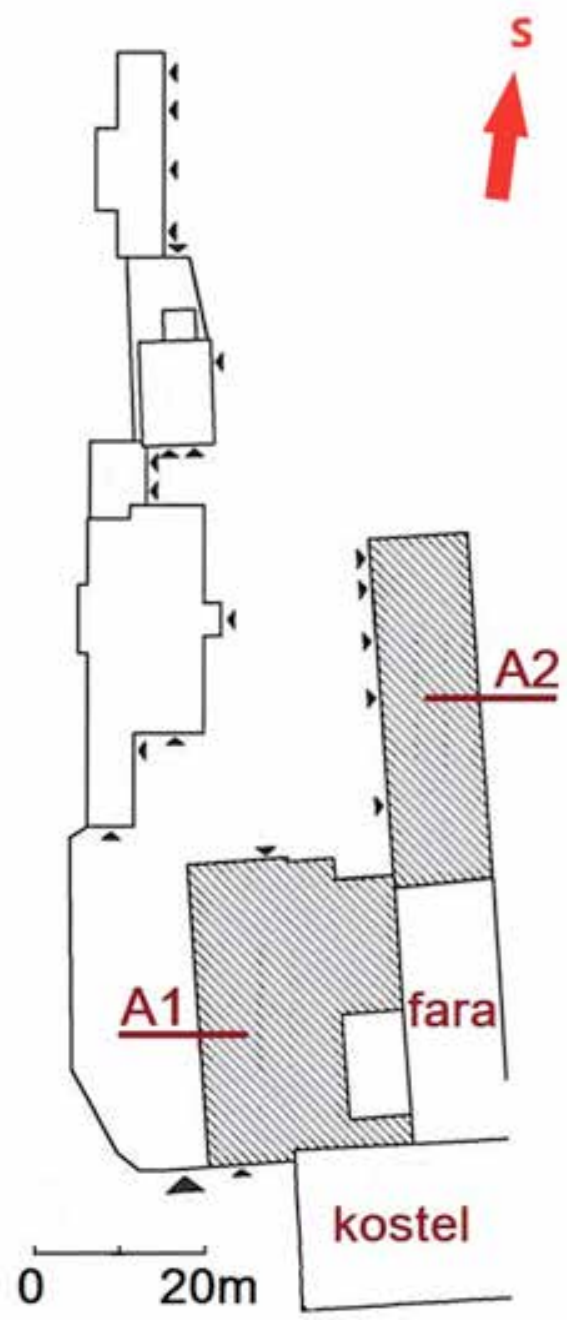

Obr. 3. Zašová, klášter, označení zkoumaných objektů na situačním plánku kláštera. A1 - západní a spojovací křídlo kolem rajského dvora; A2 - severní polovina východního křídla. Nezkoumané objekty bíle, sever nahoře. Podle Šimčík-Žurek 2016.

Abb. 3. Zaschau, Kloster, Bezeichnung der untersuchten Objekte auf dem Lageplan des Klosters. A1 - West- und Verbindungsflügel um den Paradieshof; A2 - Nordhälfte des Ostflügels. Nicht untersuchte Objekte weiß, Norden oben. Nach Šimčík-Žurek 2016. proto ještě téhož roku mohla zašovský konvent uznat jako právoplatný klášter s 13 řeholníky $\mathrm{v}$ čele s ministrem, jímž byl zvolen P. Ambrož od sv. Ignáce (Matyáš 2018, 14).

Příchodem zbylých trinitářů do Zašové se mohla jejich činnost plně rozvinout. Podle fundační listiny byli trinitáři zodpovědní za rozvoj zdejšího poutního místa a duchovní správu v regionu. $\mathrm{V}$ jistém smyslu převzali v náboženské sféře rovněž úlohu ochránce a šiřitele katolické víry, jelikož jejich přítomnost měla $\mathrm{v}$ regionu bránit snahám šírit evangelickou víru prostřednictvím kazatelů, kteří na Valašsko prricházeli z Uher (NA Praha, Čdk). Zašovští trinitáři nezapomínali ani na hlavní činnost svého řádu, a to vykupování otroků, byt' v našem př́ípadě měli tuto aktivitu zakázánu samotným císařem (Šigut 1942, 40). Bohužel není známo, kolik peněz bylo vybráno, ani kolik se podařilo vykoupit zajatců. Vedle těchto zmiňovaných aktivit rovněž trinitáři dbali o svěřený kostel a jeho vybavení (Matyáš 2018, 14).

Už v polovině 18 . století se zvýšil trinitářský kapitál z 9500 zl. na 21000 zl. z jeho úroků ve výši 850 zl. vydržovali trinitáři celý klášter (Bayer 1904, 17), který zř́jmě v tomto období (2. polovina 18. století) přestavovali (rajský dvůr) a postupně rozšiřovali. Tomu by nasvědčovaly dvě nepřímé zmínky. Zaprvé klášter dlužil rožnovské sklárně 6 zl. a 11 1/2 kr. za dodané sklo okenních výplní v roce 1757 a zadruhé v období od 1. července 1759 do 31. prosince 1769 nezaplatili zemskou daň (MZA, B 2 G-Co a, č. 1509/207; E 65 TZ). Přímé prameny $\mathrm{k}$ této otázce však mlčí. $\mathrm{Na}$ konci 60 . let pak dali průčelí kostela finální podobu, když na něm vystavěli dvojici věží (Šigut 1942, 46-47).

Život v klášteře ovšem neprobíhal jen v liturgické rovině. Obyvatelé konventu si mohli rozšiřovat obzory taktéž $\mathrm{v}$ rozsáhlé knihovně se zhruba 2500 svazky knih. Díky 
zrušovacím protokolům víme, že poslední ministr kláštera P. Anastasius od sv. Jana z Mathy měl ve své cele několik zajímavých fyzikálních přístrojů. Patřil k nim například barometr, teploměr, elektrický př́istroj či „optic“. Elektrický přístroj a dva barometry měl rovněž P. Victor a perspektiv P. Alexius (MZA, B 2 G-Co a, č. 1509/207). V knihovně se navíc nacházela malá armilární sféra (MZA, B 2 G-Co a, č. 1509/8225). V klášteře zřejmě docházelo k astronomickým a meteorologickým pozorováním i s patřičnými zápisy, jež se bohužel nedochovaly.

Stejně jako jiné kláštery i zašovský měl hospodářské zázemí. Sestávalo z včelí zahrady v lokalitě Na hrádkách v Krhové. U samotného konventu se nacházela menší zahrádka, ovocný sad, dvě políčka a několik menších luk (MZA, B 2 G-Co a, č. 1509/207). Na pozemcích kláštera se rovněž nacházely dva rybníky. V klášterní zahradě stávala kůlna na zemědělské nářadí, byt pro služebnictvo, stáj pro koně a krávy a mlékárna (MZA, B 2 G-Co a, č. 1509/8225). Podle místní tradice trinitáři na Valašsku propagovali pěstování brambor a zabývali se štěpařstvím, přičemž to měli být právě oni, kdo vyšlechtili v regionu velice oblíbenou jabloň jaderničku. Zvláštností je, že v Zašové dokonce pěstovali, sklízeli a následně i vyráběli vlastní víno, u něhož se zmiňuje odrůda ,znojemskáa“ (MZA, B 2 G-Co a, č. 1509/8225). Na některé činnosti si najímali lidi zvenčí, ale řadu prací zvládli svými vlastními silami, jelikož někteří z řeholníků byli vyučení v běžných povoláních. Takto se zmiňuje například švec, krejčí či učitel na německé škole (Šigut 1942, 54; MZA, B 2 G-Co a, č. 1509/207).

Život v klášteře se u trinitářů promítl také na jejich zdraví. Chladné prostory konventních budov a dlouhé pěší trasy se podepsaly zvláště na dolních končetinách. Hojně byly posledním trinitářům prredepisovány prostředky s projímavým účinkem. Někteří si v klášteře léčili též problémy se srdcem (MZA, B 2 G-Co a, č. 1509/207).

Slibný vývoj i působení řádu v Zašové ukončil císař Josef II. S obecnou platností byly trinitářské kláštery zrušeny 21. listopadu 1783. K zániku zašovského konventu došlo 15. prosince, kdy hrabě Karel Vincenc Salm-Neuburg přistoupil k soupisu movitého i nemovitého majetku. Sepsán byl inventář kostela, kláštera i jmění, které v různých fundacích činilo 33470 zl., v hotovosti klášter disponoval pouze $675 \mathrm{zl}$. a $10 \mathrm{kr}$. Z fundací klášteru plynul roční př́ijem ve výši 1763 zl. a 22 kr. (Šigut 1942, 59). Byt' byl klášter zrušen, trinitáři zde museli zůstat prozatímně dalšího půl roku a nadále vykonávat duchovní správu.

Po zániku kláštera byla jižní část východního křídla využita jako sídlo nové fary (1785), která zde funguje dodnes. Zbytek budov již nikdy neplnil církevní funkci (Domluvil 1914, 317; Šigut 1942, 66). Dnes patří objekt kláštera do majetku obce Zašová.

\section{Stavebně historický průzkum}

Bývalý trinitářský klášter v centru obce Zašové (Zašová čp. 45) představuje rozsáhlý areál (obr. 2) situovaný po severním boku jednolodního orientovaného barokního kostela Navštívení Panny Marie s dominantním dvouvěžovým průčelím. Jedno- a dvoupatrové budovy kláštera uzavírají nevelký vnitřní (rajský) dvůr, na severu se pak otevírají do většího prostranství s navazující zástavbou tvořící širší součást celku klášterních budov (obr. 4, 5). Severně od kláštera se nachází pozůstatky někdejší klášterní zahrady, původně hrazené zdí. Objekty bývalého kláštera, ve fasádách a zčásti i interiérech nověji upravené, mají prostá průčelí s obdélnými okny a sedlové nebo valbové střechy. Do areálu klášterních budov dále náleží dvojice hodnotných kamenných skulptur - krucifix a socha sv. Jana Nepomuckého. Areál je zapsán v Ústředním seznamu kulturních památek České republiky pod rejstříkovým číslem 19659/8-368.

V roce 2017 byl v objektu kláštera (s výjimkou části východního křídla využívané farou) realizován stavebně historický průzkum (Štětina-Vrla 2017). Provedený průzkum objektu měl převážně povrchový charakter, doplněný pouze lokálními sondážními zásahy, přinesl však poměrně výrazné obohacení dosavadních znalostí o stavebním vývoji kláštera a jeho nejhodnotnějších, barokních vývojových fázích (souhrnně Foltýn a kol. 2005; Demek-Novák 1992).

Dispozici barokního kláštera lze zcela spolehlivě rekonstruovat - sestával z dlouhého východního patrového a v celé délce podsklepeného křídla a protilehlého kratšího jednopatrového 


\section{Zašová, A1, 1.NP}

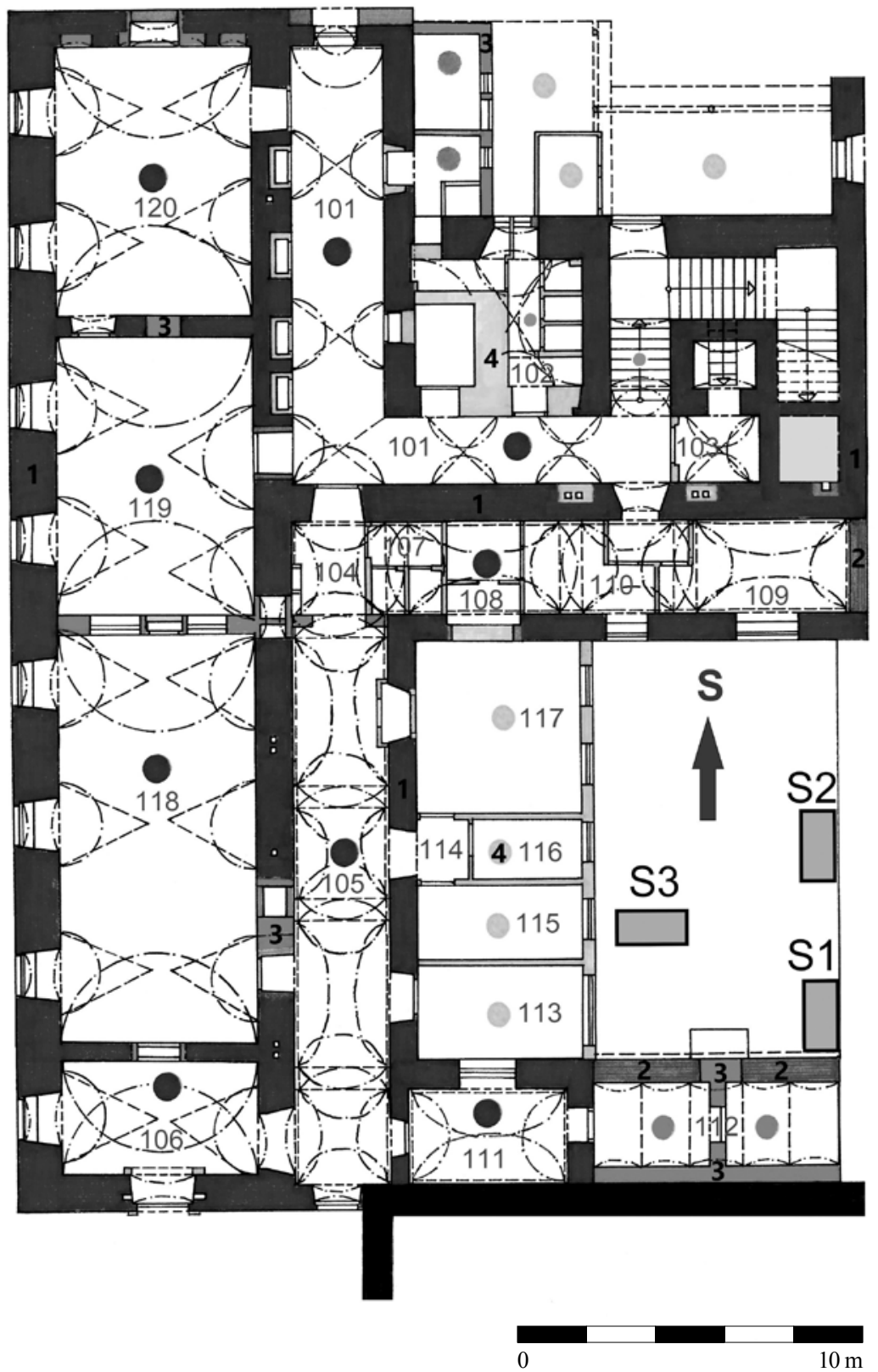

Obr. 4. Půdorys př́zemí jižní části klášterních budov (bez farní budovy) s analýzou stavebního vývoje. Tmavě šedá 1 - barokní zdiva z roku 1725 a krátce poté; stř̌edně šedá 2 - konec 18. a počátek 19. století; středně šedá 3 - průběh 19. století; světle šedá 4 - 2. polovina 20. století. Vyznačení sond archeologického výzkumu S1-S3. Podle Štětina-Vrla 2017.

Abb. 4. Grundriss des südlichen Erdgeschossteils der Klostergebäude (ohne Pfarrgebäude) mit Analyse der baulichen Entwicklung. Dunkelgrau 1 - Barockmauerwerk von 1725 und kurz danach; mittelgrau 2 - Ende 18. und Anfang 19. Jhdt.; mittelgrau 3 - Verlauf 19. Jhdt.; hellgrau 4 - 2. Hälfte 20. Jhdt. Kennzeichnung der archäologischen Sondierschnitte S1-S3. Nach Štětina-Vrla 2017. 
Zašová, A2, 1. NP
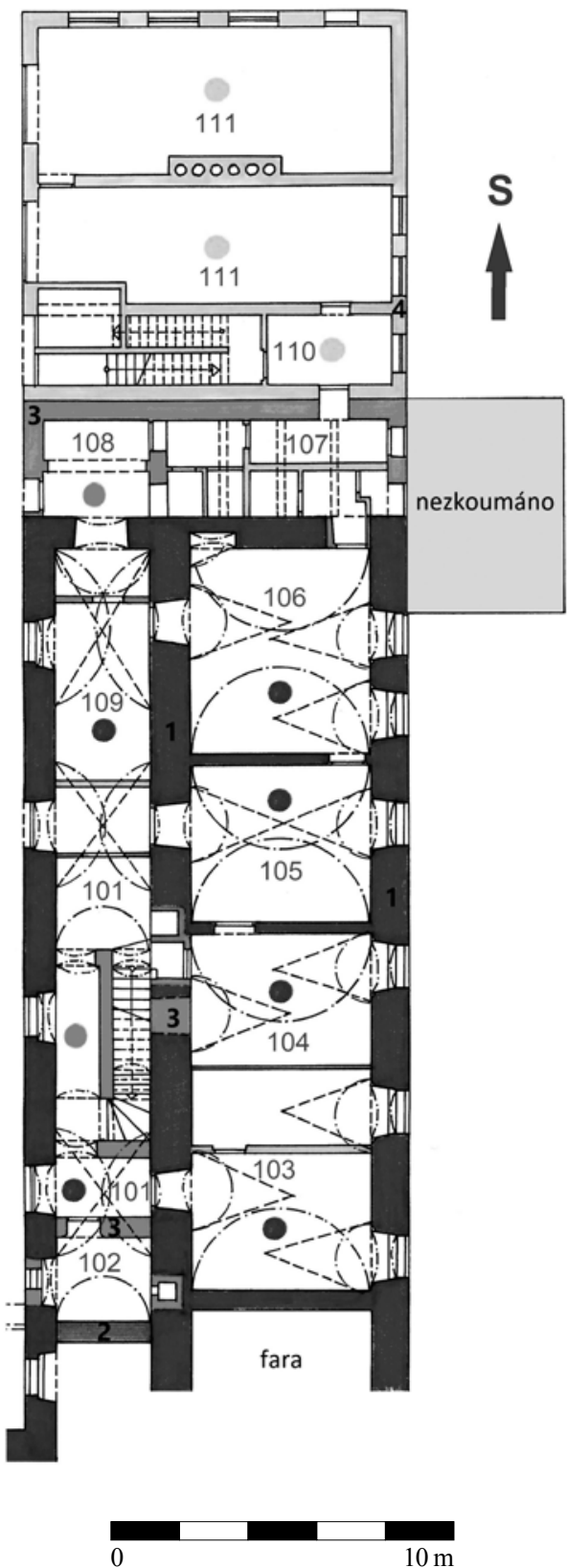

Obr. 5. Půdorys přízemí severní části východního křídla klášterních budov, vyhodnocení viz půdorys přízemí. Podle Štětina-Vrla 2017.

Abb. 5. Grundriss des nördlichen Erdgeschossteils des Ostflügels der Klostergebäude, Auswertung siehe Grundriss des Ergeschosses. Nach Štětina-Vrla 2017. a nepodsklepeného křídla západního. Obě křídla spojovalo rovněž jednopatrové zčásti podsklepené příčné křídlo, obsahující mimo jiné i hlavní dvouramenné schodiště. Nevelký vnitřní (rajský) dvůr měl čtvercový půdorys, po obvodu obestavěný přízemní chodbou ambitu, v interiéru klenutou. Na jihu na klášterní budovy navazoval rozsáhlý klášterní kostel, k němuž západní křídlo kláštera dobíhalo jednopatrovým komunikačním krčkem tvořícím krátké jižní křídlo ambitu. V patře této jednopatrové vestavby v jihozápadním koutu dvora vedl portál na kruchtu v západní části klášterního kostela. Zbytek jižního křídla byl ve formě přízemní dostavby doplněn až později. Velkoryse projektovaný klášterní komplex zůstal, patrně vlivem nedostatku financí, nedostavěn. Hypoteticky, byt's velkou mírou pravděpodobnosti lze soudit, že klášterní budovy měly mít podle původního projektu uzavřenou dispozici kolem dvou nádvoří. Tento koncept však nebyl nikdy v úplnosti naplněn - chybí severní polovina západního křídla a celé severní křídlo, které mělo zřejmě uzavírat druhé, severní nádvoří.

Datování výstavby východního křídla, jejíž počátek historické prameny vročily do roku 1725, získalo oporu i ve výsledcích dendrochronologické analýzy dřevěných prvků dochovaných $\mathrm{v}$ nádvorní fasádě východního křídla $\mathrm{v}$ podkroví nad klenbami někdejšího ambitu. Dřevěné horizontální trámy osazené v kapsách ve zdivu pravděpodobně souvisely s konstrukcí nejstaršího zastřešení ambitu, které zaniklo požárem. Letokruhová analýza určila smýcení jedle použité pro výrobu trámu do let 1725-1726 (Kyncl 2018).

Budovy kláštera měly, pokud můžeme soudit $\mathrm{z}$ dochovaného stavu, velmi jednoduché architektonické ztvárnění. $\mathrm{Z}$ architektonických prvků, které lze obvykle využít pro bližší datování nebo ztotožnění s architektonickým okruhem, v němž lze hledat navrhujícího stavitele či architekta, se dochovalo pouze několik portálů a okenních ostění. Druhou tvaroslovně citlivou skupinou stavebních prvků umožňujících bližší analýzu jsou pak detaily klenebních konstrukcí (obr. 6).

Nejnáročnějším dochovaným prvkem v areálu kláštera je vstupní portál vedoucí do přízemí západního křídla z prostranství před západním průčelím klášterního kostela. 
Obdélný portál charakterizuje plochá profilace dvojicí mělkých ustupujících pásků při vnitřním obvodu dveřního otvoru a dominantní, ovšem dosti subtilní oblý prut vsazený do další ploché lišty a obíhající vnější obvod portálu včetně uch v nadpraží. Profilace vystupuje z hranolového soklu, jehož někdejší výšku však výrazněji zkreslilo sekundární zvýšení prahu. Portál vrcholí masivní nadpražní římsou deskovitého tvaru završenou esovitě profilovanou krycí deskou, jejíž oba konce zatěžují nízké sokly s kamennými koulemi. Uvedená profilace portálu má tvaroslovné obdoby u portálů v interiéru kostela, a lze tedy předpokládat shodného navrhujícího stavitele či architekta. Zejména přítomnost masivní krycí římsové desky v nadpraží se zdá poukazovat ještě k pracím významného architekta působícího na Moravě ve službách olomouckého biskupa Karla II. z Lichtenstein-Castelcorna od roku 1666 - totiž Giovanniho Pietra Tencally. Vzhledem $\mathrm{k}$ datu Tencallova úmrtí (1702) není reálné přímé spojení výstavby zašovského kláštera s jeho invenčním vkladem. Tencallovský styl však převzala řada stavitelů či kameníků, kteří v jeho intencích realizovali své zakázky i v první polovině 18 . století prakticky po celé Moravě.

Můžeme se alespoň domnívat, že z tencallovských forem vycházel i stavitel realizující výstavbu klášterních budov v Zašové, což zřetelně dokumentuje právě portál v jižním průčelí západního křídla kláštera. Ostatně znalost charakteristických architektonických forem G. P. Tencally prozrazuje i hlavní, západní portál v průčelí klášterního kostela. Jeho základní obdélný tvar totiž po bocích obou stojek provází dvojice „,vrstvených“ pilastrů zakončených dekorativními hlavicemi. Detail plochých pilastrů po bocích portálu Tencalla ve své tvorbě s oblibou uplatňoval (viz např. portály zámku v Kroměříži, kanovnických domů v Jánské ulici tamtéž nebo obdobné detaily kroměřížské piaristické koleje z posledního desetiletí 17. století).

Další portály (např. portál s mělkou lištovou profilací a obdélným nadsvětlíkem vedoucí do sklepů pod prríčným křídlem) jsou natolik jednoduchých forem, že prakticky neumožňují přesnější časové zařazení, lze je charakterizovat pouze obecně jako barokní. Ani dochovaná ostění obdélných oken s plasticky vystupující pravoúhlou lištou na vnějším obvodu nejsou nositeli chronologicky citlivých informací, ač nepochybně vznikla již při výstavbě kláštera krátce po roce 1725 . Zcela prosté tvarosloví pak charakterizuje i další kamenicky zpracovaná okenní a dveřní ostění - například parapetní římsy oken v přízemí východního kř́ídla chodby klášterního dvora nebo zcela prostá pravoúhlou lištou opatřená ostění sklepních okének tamtéž či ostění několika obdélných portálů $\mathrm{v}$ interiéru.

Obdobná je pak i situace u klenebních konstrukcí vykazujících nejjednodušší možné, zcela obecné tvary. Výjimku zde představuje sklep pod spojovacím kř́ílem, kde je ovšem podoba kleneb výsledkem složitější dispozice, a tedy věcí nutného řešení konstrukčních, nikoliv architektonických problémů. Klenby, které přičítáme fázi výstavby po roce 1725 , jsou bezezbytku valené, opatřené trojím druhem výsečí: trojúhelnými nespojitými v př́izemí západního křídla, trojúhelnými spojitými v př́izemních, komunikačních chodbách západního a spojovacího křídla a trojúhelnými nespojitými s hroty přesahujícími podélnou osu klenby, jež se uplatnily v př́zemí východního křídla. Všechny klenební konstrukce naopak spojuje půlkruhový profil valené klenby, i mírné odsazení její paty, prosté jakéhokoliv dalšího ztvárnění nebo zvýraznění. I popsané jednoduché tvary kleneb však považujeme za natolik průkazné a časově zařaditelné, že nepochybujeme o jejich vzniku v rámci první fáze výstavby klášterních budov, tedy rovněž krátce po roce 1725 . V zásadě prezentují nejčastěji uplatňované typy barokních kleneb, jež dosáhly maximální obliby svého využití právě v desetiletích kolem roku 1700 (obr. 6).

Svislé nosné zdi klášterních budov jsou zřejmě v plné výši vystavěny z lomového pískovce pojeného vápennou maltou. Tuto strukturu vykazují pohledově přístupné lícové partie zdiv - ve sklepech, v místnostech přízemí západního křídla, ale i na vnějším průčelí východního křídla patrném z podkroví přilehlého úseku ambitu. Lomové zdivo není přesně vrstvené a vykazuje snahu po přesnějším lícování; místy je do zdiva vtroušena i cihla (nejedná se však o zdivo vykazující charakteristiky zdiva smíšeného, tedy cihlokamenného). Z lomového pískovce je zbudována i valená klenba sklepa nejstarší části kláštera, tedy východního křídla. Další, barokní klenby (ve sklepě a přízemí západního křídla a př́izemí východního křídla) jsou budovány $z$ cihel. Cihlové jsou rovněž některé interiérové špalety oken a dveří a také jejich segmentové 


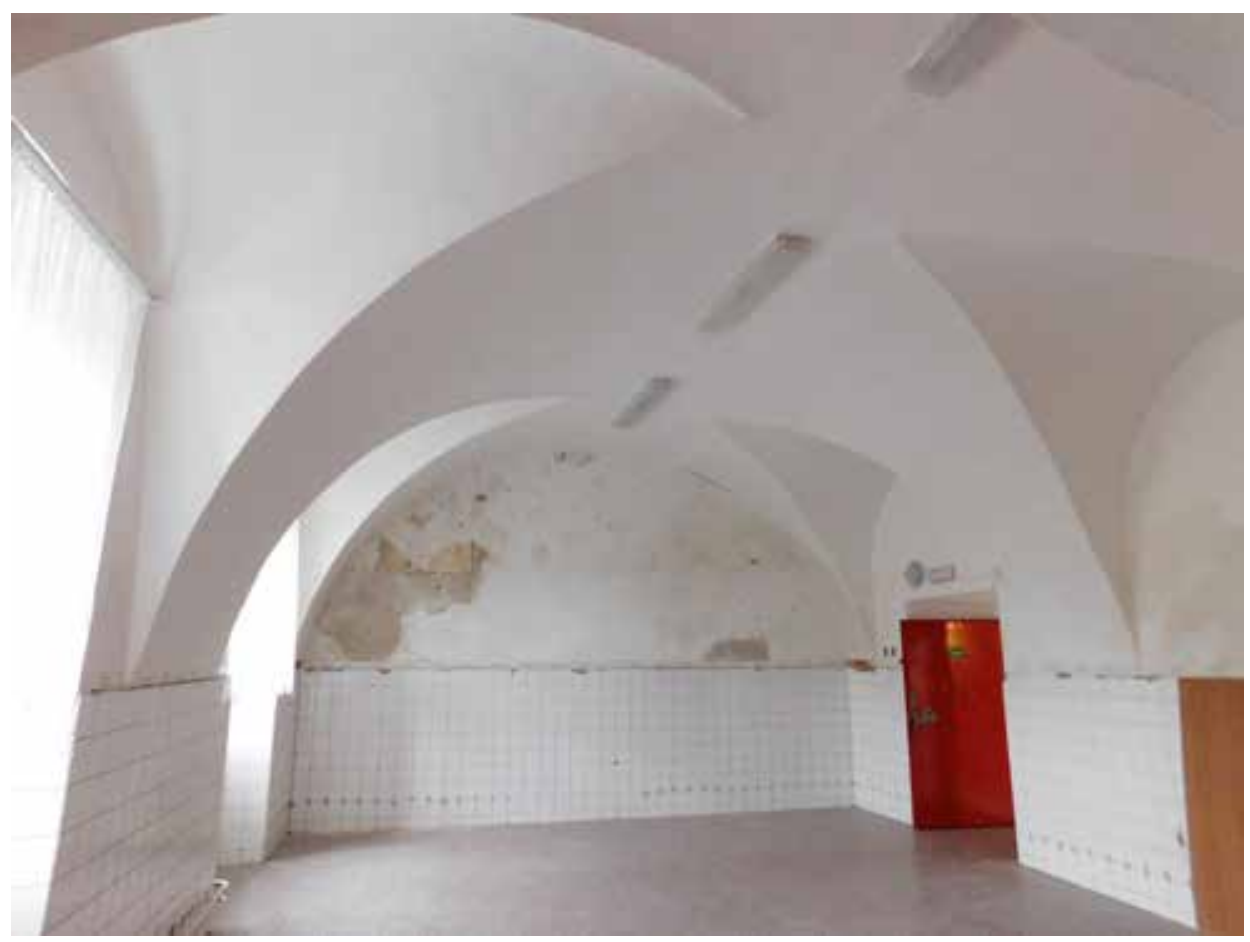

Obr. 6. Interiér jednoho ze sálů v přizemí západního křídla s typickou barokní výsečovou klenbou, krátce po roce 1725. Foto J. Štětina.

Abb. 6. Interieur eines der Säle im Erdgeschoss des Westflügels mit typischem Segmentgewölbe, kurz nach 1725. Foto J. Štětina.

záklenky. Rovněž mladší přestavby téměř výhradně využívaly cihlového zdiva, at' již při zazdívkách starých otvorů, nebo například při stavbě novějších příček. Využitá stavební technologie tedy odpovídá běžné a nejen v regionu hojně užívané praxi výstavby v barokním období. Základové poměry klášterních budov nemohly být metodami povrchového stavebně historického průzkumu zkoumány.

Architektonické ztvárnění kláštera bylo tedy zcela prosté a vyjma několika náročnějších z pískovce tesaných portálových ostění byly kamenicky opracované prvky využity pouze sporadicky - například pro tesaná ostění sklepních okének nebo v parapetních římsách oken. Povrchový průzkum doplněný sondážemi v klíčových místech objektu pomohl rovněž specifikovat rozsah mladších zásahů. Pomineme-li razantní zásahy z průběhu 20. století, obvykle se jednalo o zazdívky starších otvorů a vestavbu cihlových příček. V interiéru přízemí ambitu pak byla doložena architektonicky náročnější náhrada starších valených výsečových kleneb plackovými klenbami, jejichž střídavě čtvercová a obdélná pole dělily cihlové pasy. Jednalo se o jediný významnější zásah z doby fungování barokního kláštera, na základě uplatněných kleneb datovatelný do doby kolem poloviny 18 . století.

Zjištění, že klášterní budovy vystavěné na prahu druhé čtvrtiny 18. století měly pouze prosté architektonické ztvárnění, bez jakýchkoliv náročnějších tvaroslovných detailů, však nelze chápat ve smyslu zpochybnění kvality souboru klášterních budov. Ostatně právě klášterní funkce objektu mohla mít zrretelnou vazbu k jednoduchému architektonickému ztvárnění celku i detailů, pro zašovský komplex tak charakteristickému. Rozbor dispozice vrcholně barokních 
klášterních budov jasně diferencujících komunikační a obytné (v přízemí užitné) prostory a celkově velmi dobře zvládnutá velkorysá kompozice budovy jasně prozrazují kvalitního projektanta, jenž danou zakázku nikoliv skromného rozsahu poměrně dobře zvládl. Pokud byl projektantem autor vstupního portálu v jižním čele západního křídla kláštera (což nelze vyloučit, ale ani zcela potvrdit), vypozorovali jsme zde jeho možné tencallovské školení, což kvalitu navrhující projekční síly jen potvrzuje. V této souvislosti lze zmínit jméno stavitele Jiř́ho Kocurka z Kroměříže, jenž je na základě stávajícího stavu poznání spojován s výstavbou velkoryse pojatého a architektonicky velmi kvalitního klášterního kostela Navštívení Panny Marie. Přestože kostel vyrostl již v etapě těsně předcházející výstavbě kláštera (tedy v letech 1714-1725) a jméno jeho navrhujícího architekta neznáme, lze předpokládat účast totožného stavitele i na výstavbě časově (a dispozičně) navazujících klášterních budov. Kocurkův původ v kroměřížském prostředí, kde ještě na přelomu 17. a 18. století vznikaly stavby vzešlé z projektů již několikrát zmíněného biskupova architekta G. P. Tencally, pak představuje schůdné vysvětlení širších souvislostí kvalitní architektury zašovského kostela i několika zmíněných architektonických detailů klášterních budov.

Ostatně účast velmi kvalitních prováděcích sil při výstavbě kláštera prozrazují i řemeslně bezchybně zvládnuté detaily stavby, zřetelné především v neomítaných prostorách sklepů pod východním a středním křídlem (obr. 7). Kvalita provedení klenebních konstrukcí dokumentuje obecně velmi vysokou úroveň stavebního řemesla, $v$ našem prostředí charakteristickou zejména pro barokní období. Ani tato kvalitativní rovina by v případě architektonicky jinak poměrně prostého celku klášterních budov v Zašové neměla zůstat opomenuta.

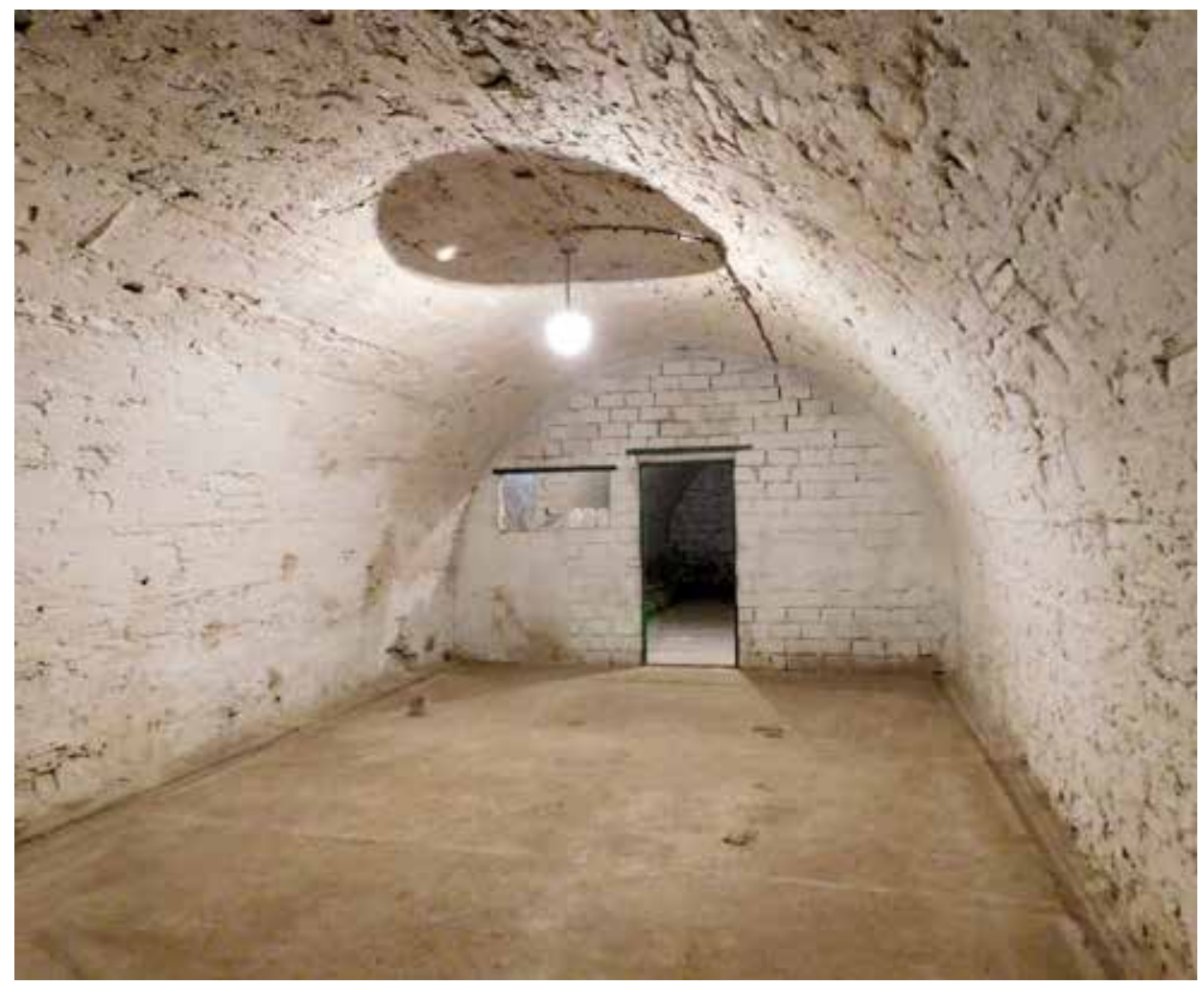

Obr. 7. Interiér sklepa pod severní částí východního křídla z roku 1725. Foto J. Štětina.

Abb. 7. Interieur des Kellers unter dem nördlichen Teil des Ostflügels aus dem Jahr 1725. Foto J. Štětina. 


\section{Archeologický výzkum}

Obec Zašová se jako nový majitel kláštera rozhodla přistoupit $\mathrm{k}$ jeho rekonstrukci s konečným cílem vytvořit $\mathrm{v}$ jeho prostorách komunitní a kulturní centrum. V letech 2016 a 2017 proběhla prvá fáze rekonstrukčních prací, které si vyžádaly výzkum rajského dvora. V rámci této akce byly položeny tři sondy: S1 v jihovýchodním rohu pod oknem se sklepní přepážkou, S2 při východním vstupu na dvůr a S3 jižně od betonové skruže, která překryla původní centrální studnu (obr. 4).

Základní nálezová situace byla ve všech třech sondách stejná (obr. 8). Po odstranění betonového dláždění z poloviny 20. století a jeho pískového lože (100) jsme narazili na vertikálně kladenou štětovou dlažbu z říčných valounů (902), která byla vyspárovaná černou hlínou smíchanou s pískem (102). Pod touto vrstvou se nachází jílovitá vyrovnávka terénu, která obsahovala první větší množství keramiky, skla a kostí (103). Při východní straně rajského dvora se v této vrstvě táhlo odpadové potrubí. Další úrovní byla opět štětová dlažba (903), místo valounů byl však použit lomový kámen, jenž byl kladen mnohem pečlivěji a hustěji než valouny v mladší vrstvě. I tato dlažba byla vyspárovaná černou hlínou (104). Pod touto dlažbou byla už jen vrstva hlíny smíchaná s jílovým podložím (105). Tento kontext interpretujeme jako vyrovnávku terénu vzniklou při skopávání vrcholové partie návrší, během kterého bylo dosaženo podloží (106). Po zarovnání podloží (které se nachází již pod touto vrstvou) posloužila jako podkladní vrstva pod první dlažbu.

V sondě S1 byla zachycena jáma krychlovitého tvaru (502), která porušovala všechny vrstvy mimo recentního dláždění a jeho pískového podkladu a byla zahloubená až do podloží (obr. 9 , 10). Jáma byla částečně u zdi kláštera překryta nesouměrnou směsí cihel, dlaždic a malty $(900)$. Zásyp obsahoval velké množství keramiky - hrnčiny i fajánse, dále kosti a sklo. V její blízkosti byla zachycena další, menší válcovitá jáma, která začínala v úrovni starší dlažby a taktéž byla zahloubena do podloží. Tato jáma však neobsahovala žádné movité nálezy. Větší jáma byla

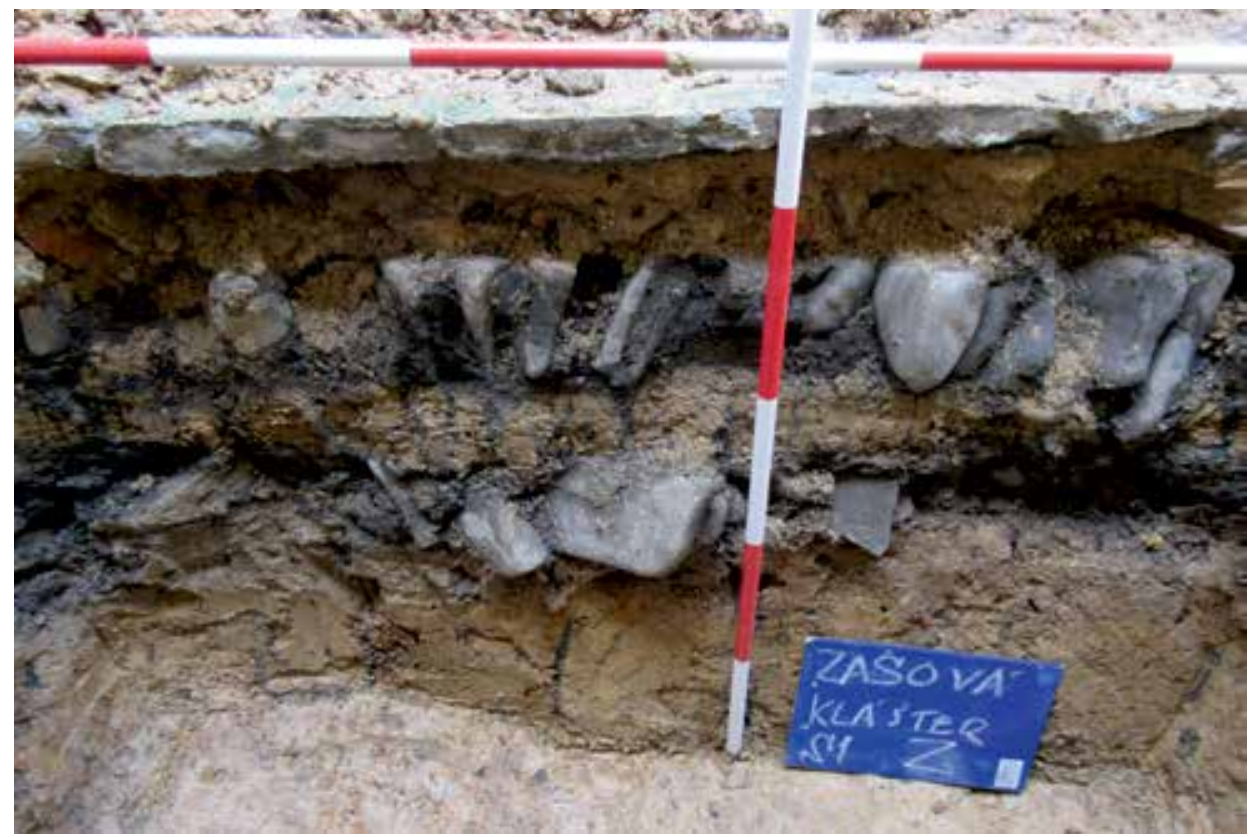

Obr. 8. Základní nálezová situace, sonda S1, západní profil. Foto S. Španihel. Abb. 8. Fundgrundsituation, Sondierschnitt S1, Westprofil. Foto S. Španihel. 


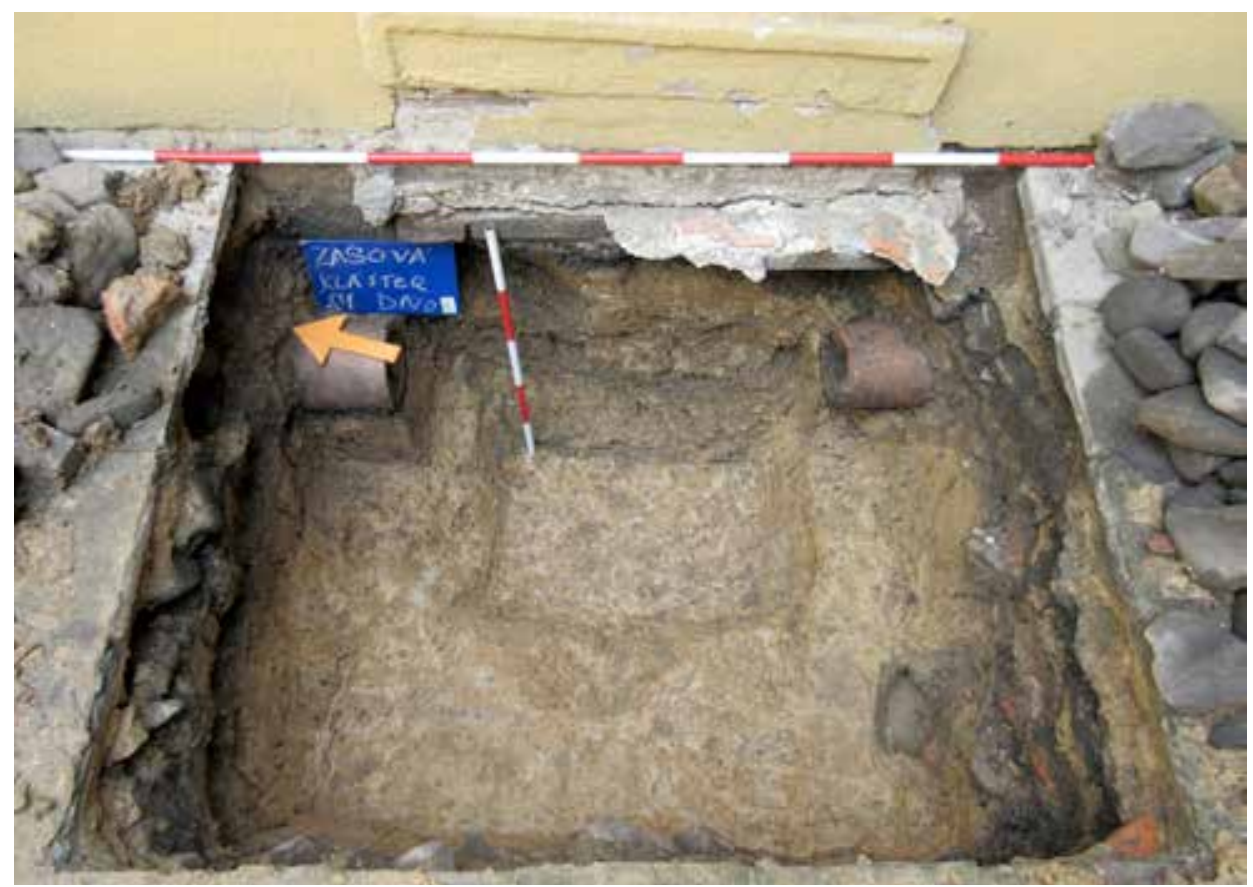

Obr. 9. Odpadová jáma v sondě S1. Foto S. Španihel.

Abb. 9. Abfallgrube in Sondierschnitt S1. Foto S. Španihel.

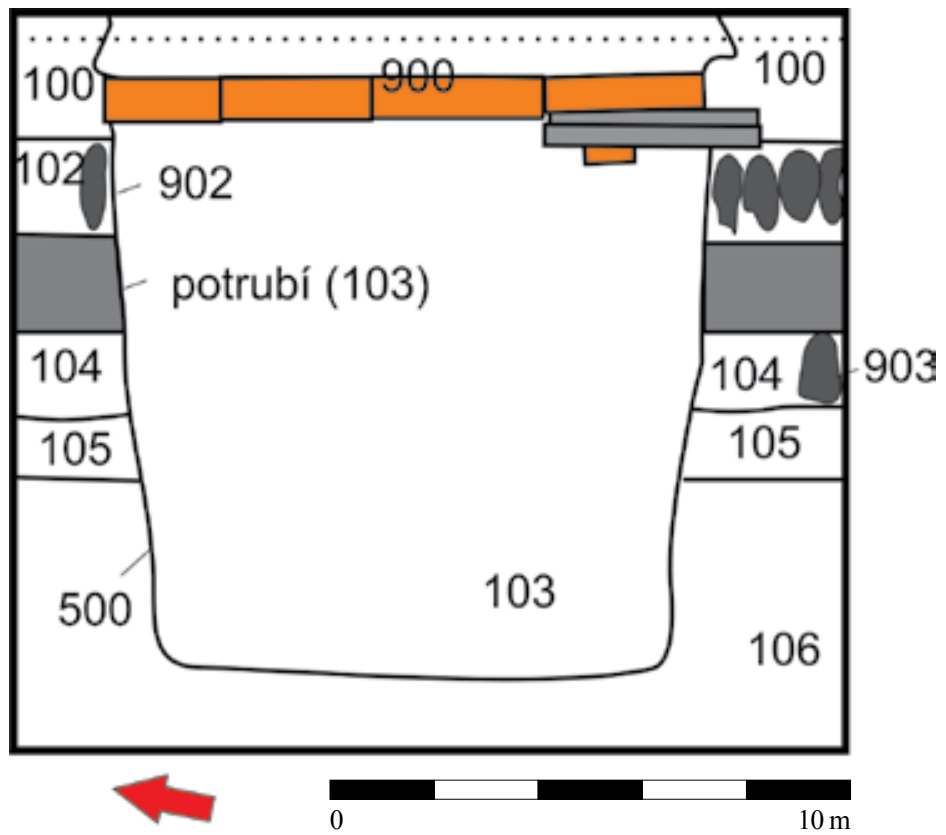

Obr. 10. Profil sondy S1 s odpadní jámou. Kresba S. Španihel.

Abb. 10. Profil von Sondierschnitt S1 mit Abfallgrube. Zeichnung S. Španihel. 
pravděpodobně vyhloubena $\mathrm{v}$ závěrečné fázi existence kláštera jako sakrálního objektu, nebo těsně po jeho zániku, protože obsahuje předměty (viz rozbor nálezů), které se pojily přímo s životem místních řeholníků a pro nové nájemce asi neměly valnou hodnotu. Podle homogennosti zásypu je možné předpokládat, že jáma byla naplněna v krátkém časovém úseku. Menší jámu neumíme interpretovat.

V sondě S2 nacházející se u východního vchodu do rajského dvora byly odhaleny kamenné schody, které klesaly až na úroveň starší dlažby. Schody byly z monolitických kvádrů, přičemž poslední byl na úrovni dlažby obložen načervenalým pískovcem. Během zvyšování úrovně rajského dvora se schody postupně ztrácely v nových vrstvách a po vydláždění v 20. století zůstala trčet jenom část nejvrchnějšího schodu, který posloužil jako práh.

Exkavace sondy S3 dokázala, že rajský dvůr měl i v centrální části stejnou niveletu jako ve východní části. Taktéž byla zjištěna zděná dvojstupňovitá konstrukce kolem studny, pravděpodobně hexagonálního nebo oktogonálního tvaru. Jednotlivé stupně byly vyloženy pískovcem, stejným, jaký byl použit na obklad schodů v sondě S2. Na mladší dlažbě bylo zachyceno několik fragmentů cihel a střešních tašek, které se seskupovaly v jihozápadní části sondy a pravděpodobně představují destrukci blíže neidentifikovatelné menší stavbičky stojící u studny, nebo část její nadzemní úpravy (Španihel 2016; Španihel-Zbránková 2017).

K stavební podobě kláštera nepřinesl tento drobný výzkum žádné další informace, které by rozšířily výsledky stavebně historického průzkumu.

\section{Keramický soubor}

Nalezenou keramiku (398 fragmentů, z kterých se nám podařilo identifikovat 318 jedinců) dělíme na dvě základní skupiny: hrnčinu $(61,9 \%)$ a fajáns $(38,1 \%)$. Převážná většina nálezů (76,3\%) pochází z odpadní jámy, která byla exkavována v sondě S1, ostatní střepy, kromě tří drobných jedinců zachycených v sondě S3 $(0,8 \%)$, byly získány převážně z jílovité vyrovnávky terénu mezi dvěma dlažbami (24,9\%). I když jsme vzhledem k rozdílnému typu kontextu očekávali rozdílnou fragmentarizaci u nálezů z vyrovnávky a odpadové jámy, tento předpoklad se nepotvrdil a po rozdělení do tř́i základních velikostních skupin, skupina $1-$ do $3 \mathrm{~cm}^{2}$, skupina $2-3-6 \mathrm{~cm}^{2}$ a skupina 3 - nad $6 \mathrm{~cm}^{2}$, byl poměr jednotlivých skupin u obou celků přibližně stejný. První skupina byla zastoupena v S1 196 jedinci k 45 jedincům, druhá skupina $87: 20$ a třetí skupina $43: 12$. Tento fakt poukazuje pravděpodobně na to, že vyrovnávací vrstvy, stejně jako chronologicky mladší výplň odpadové jámy vznikly během velmi krátké doby.

Hrnčina je reprezentována keramikou s načervenalým až okrovým střepem, který je typický pro oblast karpatského oblouku (Hoššo 1988, 11). Jako ostřivo je použit prach, příležitostně jemný písek, nádoby jsou dobře vypálené, jednotné barvy i kvality po celém povrchu. Typologicky jsou v této kategorii doloženy hrnce, džbány, hrníčky, misky, trojnožky, hluboké mísy, taliřrovité mísy, cedníky a zvoncovité pokličky. K šlechtění keramiky byla použita transparentní olověná glazura (doložena byla bezbarvá, zelená a černá [burelová] varianta), nebo, a to jenom velice ojediněle, neprůhledná glazura s kovovým leskem (Španihel 2014 144, tab. 1). Transparentní olověná glazura je př́ležitostně kombinována s bílou hlinkou. Podíl glazované keramiky je $91 \%$. Glazované jsou zejména vnitřky nádob, a to transparentní bezbarvou glazurou, ve $12 \%$ prrípadů transparentní zelenou. Podklad z bílé hlinky je doložen na $16 \%$ polévaných nádob.

Nejpočetnější nádobou je samozřejmě hrnec (44ks). Kromě klasických novověkých amforovitých a soudkovitých tvarů jsou zde doloženy i tři fragmenty pecních hrnců (tab. 1:4), které jsou glazovány glazurou s kovovým leskem a mají široké dno, byly tedy určeny k spodnímu ohřevu. Zastoupeny jsou dva typy okrajů. Jednoduché vykloněné se dělí na zaoblené ( $4 \mathrm{ks}$, tab. 1:1), přehnuté ( $2 \mathrm{ks}$, tab. 1:2), s proláknutou vnitřní částí (3 ks, tab. 1:3) a ostře lomeným hrdlem ( $2 \mathrm{ks}$, tab. 1:4). Druhou skupinu tvoří tzv. pozdní nebo nepravá okruží (5 ks, tab. 1:5). Jde o běžné typy okrajů rozšířené na velkém území východní části střední Evropy (např. Španihel 2016, 158, tab. 2; 2017, 300, obr. 5). Všechna ucha $(5 \mathrm{ks})$ jsou pásková konvexní, v jednom př́ípadě se vyskytla výzdoba dvěma vertikálními rýhami v kombinaci s otiskem prstu v tělové části nádoby. 


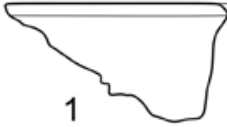

1
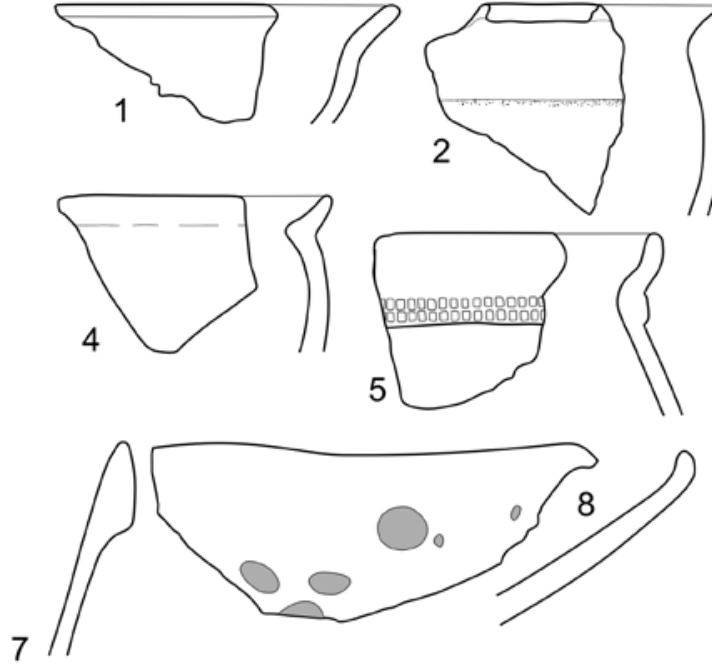

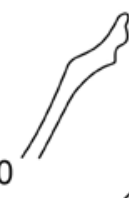

11

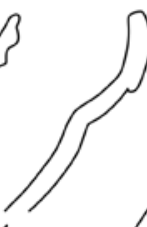

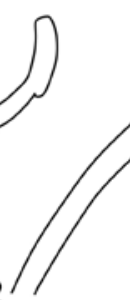
13

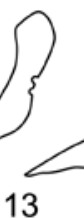
3
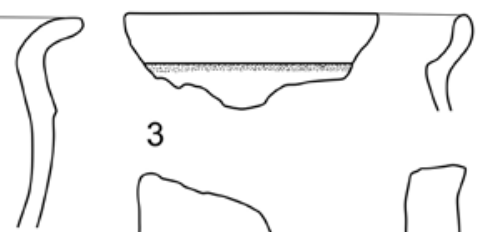

3

6
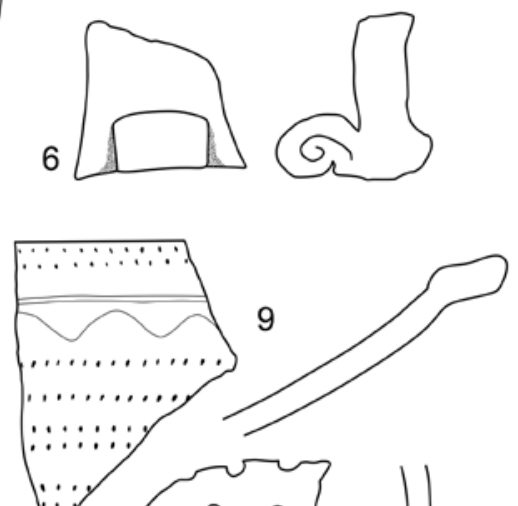

Tab. 1. Výběr hrnčiny - porézní keramiky. Kresba T. Kašparová.

Tab. 1. Auswahl an Irdenware - poröser Keramik. Zeichnung T. Kašparová.

Polovina fragmentů (prakticky všechna dna a spodní části nádob) je začouzená, jde tedy o kuchyňskou keramiku. Průměr okraje dosahuje 13 až $18 \mathrm{~cm}$, průměr dna 10 až $13 \mathrm{~cm}$ (dochované dno pecních hrnců má $18 \mathrm{~cm}$ ). Hrnek je zastoupen jedním větším fragmentem (ø dna $8 \mathrm{~cm}$ a okraje $12 \mathrm{~cm}$ ) a dvěma okraji, stejnými jako u většího zlomku, u nějž jde o jednoduchý vykloněný typ s proláknutou vnitřní částí. Fragment a jeden z okrajů je oboustranně glazován transparentní černou glazurou. Druhý okraj má vevnitř transparentní zelenou glazuru. Obdobná situace je u džbánu. Jedenáct fragmentů výdutě a hrdla je oboustranně glazováno, kromě barevné kombinace všech výše zmíněných variant transparentní glazury byla použita také bílá hlinka jako podklad. Zajímavostí je plastická výzdoba ucha džbánu v podobě šneka či spirály (tab. 1:6). Tento fragment i několik dalších, které se nám podařilo určit jako součást jedné nádoby, dokládají celoplošné glazování (povrch transparentní černou glazurou, vnitřek transparentní bezbarvou). I když neznáme přesnou podobu džbánu, šnekovitá ozdoba a plošné glazování nacházejí analogii v nádobě, která pochází z keramického souboru nalezeného v klášteře kamaldulů na nitranském Zoboru, jenž je datován mezi roky 1760-1782 (Samuel-Čurný 2012, 440, 447).

Výzdoba vyšších hrncovitých nádob je poměrně jednoduchá, omezuje se na různý počet rýh (1-4 rýhy u 19 jedinců) a žlábků (2-4 žlábky u 3 jedinců) na pleci nádoby. U jednoho jedince bylo doloženo jednoduché radélko v podobě dvou nad sebou umístněných čtverců. U tř́ jedinců se vyskytly kapkovité či kulaté fleky z transparentní zelené glazury na bílé hlince překryté transparentní bezbarvou glazurou. Tyto dekory zmiňuje V. Scheufler jako typické pro druhou 
a třetí keramickou skupinu valašskomeziříčského výrobního okruhu 18. až 20. století (Scheufler 1972, 145, př́loha obr. 62, 74).

$\mathrm{Z}$ trojnožky je doložen jenom silně přepálený fragment. Okraj je vykloněný, trojúhelníkově ovalený (tab. 1:7), ploché dno o průměru $16 \mathrm{~cm}$, u kterého se zachovala jedna prohnutá, poměrně krátká nožka $(5 \mathrm{~cm})$. Nádoba je vevnitř glazovaná transparentní bezbarvou glazurou. Mísy (11 ks) mají dva typy okrajů - jednoduchý ovalený zatáhnutý (3ks, tab. 1:8) a hraněný vodorovný vykloněný typ (tab. 1:9). Průměr okraje je u měřitelných zlomků shodný $-38 \mathrm{~cm}$. Vnitřek čtyř mís je v základě zdoben již zmíněným zeleným flekatým dekorem valašskomeziříčského výrobního okruhu (tab. 1:8). Pod ním je dvakrát doložená rytá výzdoba - blíže nerozpoznatelné geometricko-rostlinné útvary a pak jednoduché gilošování v kombinaci s vlnovkou (tab. 1:9). Přidání bílé hlinky jako kontrastního podkladu pod glazuru se objevuje šestkrát, ale nikdy se nekombinuje s rytou výzdobou. Ostatní nádoby jsou jenom prostě glazovány transparentní bezbarvou glazurou, s okrajem oboustranně zvýrazněným transparentní zelenou glazurou. Hluboké mísy s talířovým podokrajem jsou zastoupeny $27 \mathrm{krát}$, přičemž převažují okraje. Ty je možné rozdělit na jednoduché tvary a pozdní okruží s lištou. Jednoduché tvary variují od mírně vykloněného typu s proláknutou vnitřní částí (1 ks, tab. 1:10) až k dominujícím ovaleným zatáhnutým typům (7 ks, tab. 1:11). Pozdní okruží s lištou je doloženo dvakrát (tab. 1:1:12). Dochované okraje umožňují zjistit průměr nádoby, jenž se pohybuje v rozmezí 34 až 38 centimetrů. Výzdoba odpovídá plytčím mísám, flekatý dekor je zastoupen čtyřikrát, zbytek nádob je glazován transparentní bezbarvou glazurou, s okrajem oboustranně zvýrazněným transparentní zelenou glazurou. Výjimkou jsou dvojice rýh pod okraji doložené u dvou střepů. Tři zvoncovité pokličky jsou rovné, dochované držadlo má profilovaný knoflíkový charakter (tab. 1:13). I zde se ve dvou případech vyskytl flekatý dekor, přičemž jedna poklička je navíc zdobená dvěma žlábky. Dvě dochované misky se od sebe velmi liší. První je nízká neglazovaná kónická nádoba o výšce $3 \mathrm{~cm}$ (ø dna $17 \mathrm{~cm}$ a okraje $18 \mathrm{~cm}$ ), s plochým dnem a jednoduchým vykloněným zaobleným okrajem. Druhá, dochovaná jenom ve fragmentu, má sice stejný okraj, ale má vypouklé tělo a je oboustranně pokryta bílou hlinkou, na vnitřní straně je navíc glazovaná kombinací transparentních glazur: zelené a bezbarvé. Okraje obou typů mís i trojnožky jsou běžnou záležitostí a nacházíme je na stejně širokém území jako okraje vyšších nádob (Pajer 1983, 28, obr. 5:1, 3, 7; 29, obr. 7:5, 6; 31, obr. 8:1-5). Posledním typem hrnčiny je cedník, dochovaný je však jenom fragment plochého dna s otvory, proto není možné se k této nádobě vyjádřit blíže (tab. 1:14).

Jak bylo zmíněno, fajáns tvoří přibližně jednu třetinu nálezového fondu. Jde o velmi kompaktní soubor skládající se v zásadě jenom z talířů, mís a vyšších soudkovitých nádob. Plytké nádoby tvoří absolutní většinu, protože vyšším nádobám je možné přiradit jenom tři střepy. Talíře (21 ks) jsou si velmi podobné. Základní tvar představuje nízkou plytkou kruhovou nádobu, jejíž výška (podle lépe dochovaných fragmentů) činí 3 až $4 \mathrm{~cm}$ (tab. 2:1, 2). Z tohoto základního tvaru se vymezují hluboké ( $9 \mathrm{ks}$ ) mísy s výškou přibližně $10-15 \mathrm{~cm}$ (tab. 2:3-10). Jde o větší nádoby, jejichž průměr okraje se pohybuje v rozmezí 32 až $38 \mathrm{~cm}$. Talíře naopak nepřekračují $32 \mathrm{~cm}$ v průměru a neklesají pod $16 \mathrm{~cm}$. Dvě z mís mají tyčinkovité uši. $\mathrm{V}$ jednom př́ípadě je možné pozorovat náznak tordování.

Oba typy nádob sdílejí společné znaky. Dno je rovné (6ks), často doplněné drobným žlábkem po obvodu, nebo je odsazené na nízké patce $(6 \mathrm{ks})$, a to hranaté nebo oblé. Tělo nádoby je vždy vypouklé a minimálně jednou horizontálně členěné odsazením, čímž se vytváŕí nevýrazný podokraj. Jednoduché vykloněné okraje ( $26 \mathrm{ks})$ se dělí na dvě skupiny. Prvním typem jsou zaoblené tvary, které je možné dále rozdělit na základní tvar (tab. 2:3, 6, 8, 10) a jeho ven prohnutou variantu (tab. 2:1,2). Druhý typ (4ks) reprezentují zaoblené okraje s vnitřním proláknutím (tab. 2:4, 9).

Výzdoba, která je doložená jenom u mís, se dělí také na dva druhy. Početnější je zvlnění okraje, zaznamenáno je několik typů (tab. 2:4-7). Ojediněle je zvlněný okraj doprovázen žebrováním těla nádoby (tab. 2:7). Druhým dekoračním postupem je malování. Doloženy jsou čtyři obrázky. První dva (tab. 2:3,8) reprezentují jednoduché, tzv. elementární rostlinné motivy (zelené lístky, žluté kytičky) vycházející z všeobecné novokřtěnecké tradice (např. Pajer 2011, 31, 

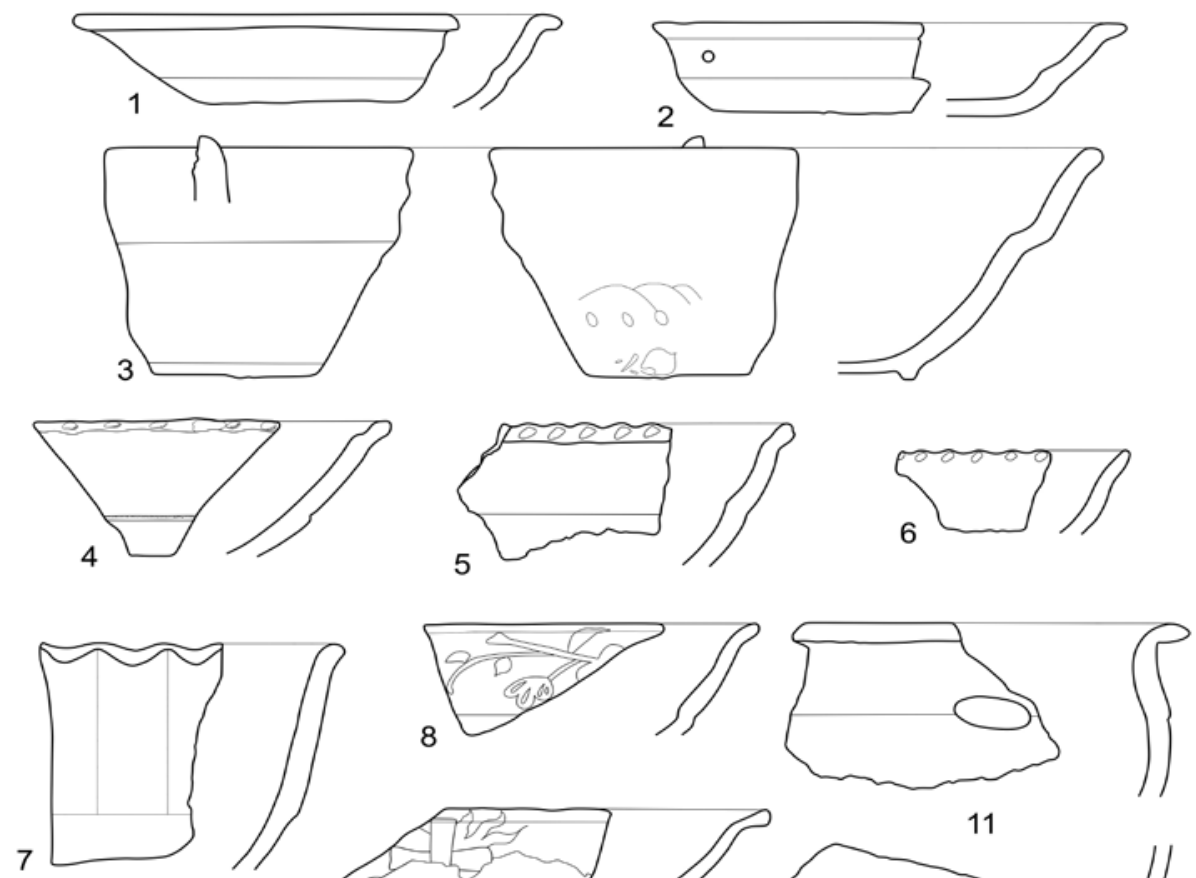

11
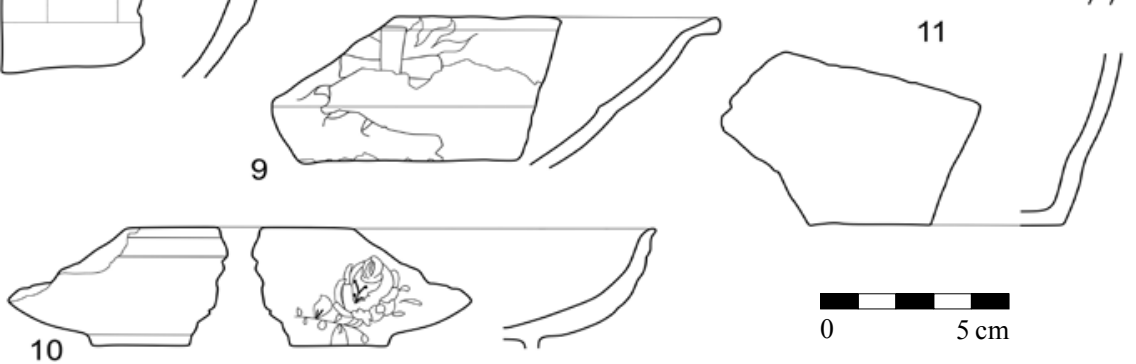

0

$5 \mathrm{~cm}$

Tab. 2. Výběr fajáns. Kresba T. Kašparová.

Tab. 2. Auswahl an Fayancen. Zeichnung T. Kašparová.

obr. 40; 33, obr. 44; 54, 55 a další). Naopak velmi zajímavou dekorací je zobrazení trinitářského kř́žže (již zmíněná kombinace červeného a modrého ramene) v kombinaci s dvanácticípou hvězdou, která odkazuje na Pannu Marii (tab. 2:9). Tento motiv očividně vznikl na objednávku zašovských řeholníků, protože př́mo odkazuje jednak na jejich řád a jednak na místní mariánský kult, který je spojen s poutním kostelem, pramenem posvátné vody Stračka a obrazem Panny Marie Zašovské. Posledním motivem je květ růže (tab. 2:10), který také nepatří mezi původní habánské dekory. Kvalita provedení růže a použití červené barvy, která se na začátku druhé poloviny 18. století začínala objevovat mezi džbánkaři, a tedy i mezi meziř́ičskými tufarníky (Šujan 1982, 6-7; Urbachová 1986, 19), nasvědčuje, že jde také o specifickou zakázku, protože kromě hvězd je i květ růže významným mariánským symbolem (souhrnně Horáková 2017, 27).

Na třech talírích se vyskytly reparační otvory (tab. 2:2), které sloužily k opravě nádoby, a to stažením drátem. Takováto forma opravy samozřejmě nevrátila nádobě její plnou funkčnost, ale svědčí o jejím delším využívaní a specifické důležitosti pro jejího majitele (Samuel-Čurný 2012, 440). 
Dva fragmenty vyšších soudkovitých nádob jsou pravděpodobně části hrnků (tab. 2:11). $\mathrm{K}$ tomuto závěru jsme dospěli na základě rekonstruovatelného tvaru, reliktu páskového ouška a jednoduchého vyhnutého zaobleného okraje (Pajer 2006, 81, obr. 2:5). Poslední fragment se stejným typem okraje, ale bez ucha je pravděpodobně albarello (Pajer 2006, 159, obr. 27).

Vzhledem k existenci soudobých dílen na výrobu fajánse ve Valašském Meziříčí a několika prokázaným analogiím (Černohorský 1941a, př́iloha mísy obr. 155, 172; talíře obr. 149, 183) se domníváme, že zkoumaná kolekce pochází z těchto dílen. Absenci barevné výzdoby na talírích přisuzujeme předepsané chudobě jednotlivých členů žebravého rádu, s čímž zřejmě souvisí i reparační otvory. Naopak mísy, které sloužily k společnému stravování nebo k přerozdělování jídla, nesly konkrétní výzdobu reprezentující řád, respektive klášter jako celek. Otázkou je vztah hrnčiny a fajánse v klášterním prostředí. Když z hrnčiny vyloučíme hrnce, trojnožky, cedník a zvoncovité pokličky, které jsou jasně spojeny s uchováváním surovin a přípravou jídla (což dokládá např́íklad začouzení stěn a den hrnců), zůstane několik džbánů, hrníčků, mís a misek. Jde tedy o dva typy nádobí určeného k stolování. Jejich vztah se dá předpokládat v několika rovinách. Zaprvé oba typy mohly být použivány společně. Fajánsové talíře jako hlavní alimentační nádoby spolu se servírovacími mísami, které byly doplněny výrobky z hrnčiny. Zadruhé mohla být k běžnému stravování řeholníků používána obyčejná keramika a fajáns se použivala během svátků, půstů nebo jiných slavnostních událostí. Samozřejmě možná je i opačná verze - běžně se používala fajáns a obyčejná keramika sloužila jako postní nádobí (Štajnochr 2006, 974). Zatřetí je možné, že bílou keramiku používali trinitáři a hrnčina byla vyhrazena pro klášterní laiky (výjimku asi tvořilo několik džbánů, např́íklad exemplář se spirálovitou ozdobou).

\section{Soubor skla}

Nejpočetnější nálezy skla v oblasti areálu klášterního komplexu v Zašové pocházejí z odpadové jámy označené jako S1. Zde se nacházelo jak sklo tabulové, tak duté sklo bez malířského dekoru nebo broušení (až na dvě výjimky). Zlomky tabulového skla jsou tř́i typů kvality, o tloušt'ce 1-2 mm. Mezi nimi vyniká nález čirého skla s minimem nečistot, na kterém jsou ve vzdálenosti $14 \mathrm{~mm}$ vyryty dvě linie. Pravděpodobně se jedná o dekorativní pásky skleněné výplně nábytku.

Naprostá většina střepů však pochází ze skla dutého. Převažuje čiré sklo s modrozeleným nádechem, výjimku tvoří jen dva střípky (plocha kolem $1 \mathrm{~cm}^{2}$ ) skla kobaltově modré barvy. Světlejši modrý odstín má i jediný skleněný korálek (ø $10 \mathrm{~mm}$, ø otvoru $2 \mathrm{~mm}$, lehce zploštělý), který byl v rámci archeologického průzkumu lokality nalezen.

Skleněné střepy dokládají, že sklo bylo foukáno do rotačních dřevěných forem, ale mezi nálezy jsou i střepy vykazující použití optických předforem. Jedná se o lahev s protaženým hrdlem opatřeným prstencem s hutně navinuté skleněné nitě, jejíž vyduté tělo bylo vertikálně žebrováno (tab. 3:1). Z podobně veliké lahve (na víno?) se dochoval ještě hutně vinutý prstenec z hrdla (ø $32 \mathrm{~mm}$ ). Stopy využití předforem nesou i poměrně veliké (délky až $115 \mathrm{~mm}$ - viz tab. 3:2) střepy se žlábkovým projmutím z nazelenalého čirého skla, u nichž lze s ohledem na sílu střepu (3-4 mm) také předpokládat větší objem. Další dvě části hrdel (viz tab. 3:3, 4) už jsou menšího průměru ( 35 a $24 \mathrm{~mm}$ ) a pocházejí z menších lahví. Menší objem dutého skla dokládají i nalezené úlomky den lahví (jedna s výrazným projmutím, viz tab. 3:5). Ty umožňují odhadnout průměr nádob - takto lze přibližně určit průměr pěti nádob na $5 \mathrm{~cm}$, dvě nádoby měly průměr $7 \mathrm{~cm}$ a $8-9 \mathrm{~cm}$ a největší nádoba měla průměr asi $11 \mathrm{~cm}$. S ohledem na historii kláštera se mohlo jednat o sklo určené pro uchovávání léčiv. Tomu by nasvědčoval i střep (tab. 3:6) s částí rytiny: na ploše o velikosti asi $8 \mathrm{~cm}^{2}$ je vyryto písmeno $\mathrm{P}$ a spodní část písmene s patkou (zřejmě A, prrípadně X), které je z levé strany lemováno páskem obloučků se zářezy doplněnými ve spodní části vegetabilním ornamentem (trojlístek). Nápis v dekorativní kartuši mohl být označením lékárenské zásobnice. Analogie k takto dekorovaným rytým štítkům na lékovkách lze dohledat např́iklad v barokní lékárně v Kuksu, kde jsou obloučky zdobené štítky s nápisy navíc zlaceny. Výrobce lékovek je vzhledem k jejich tuctovosti prakticky nemožné určit. 


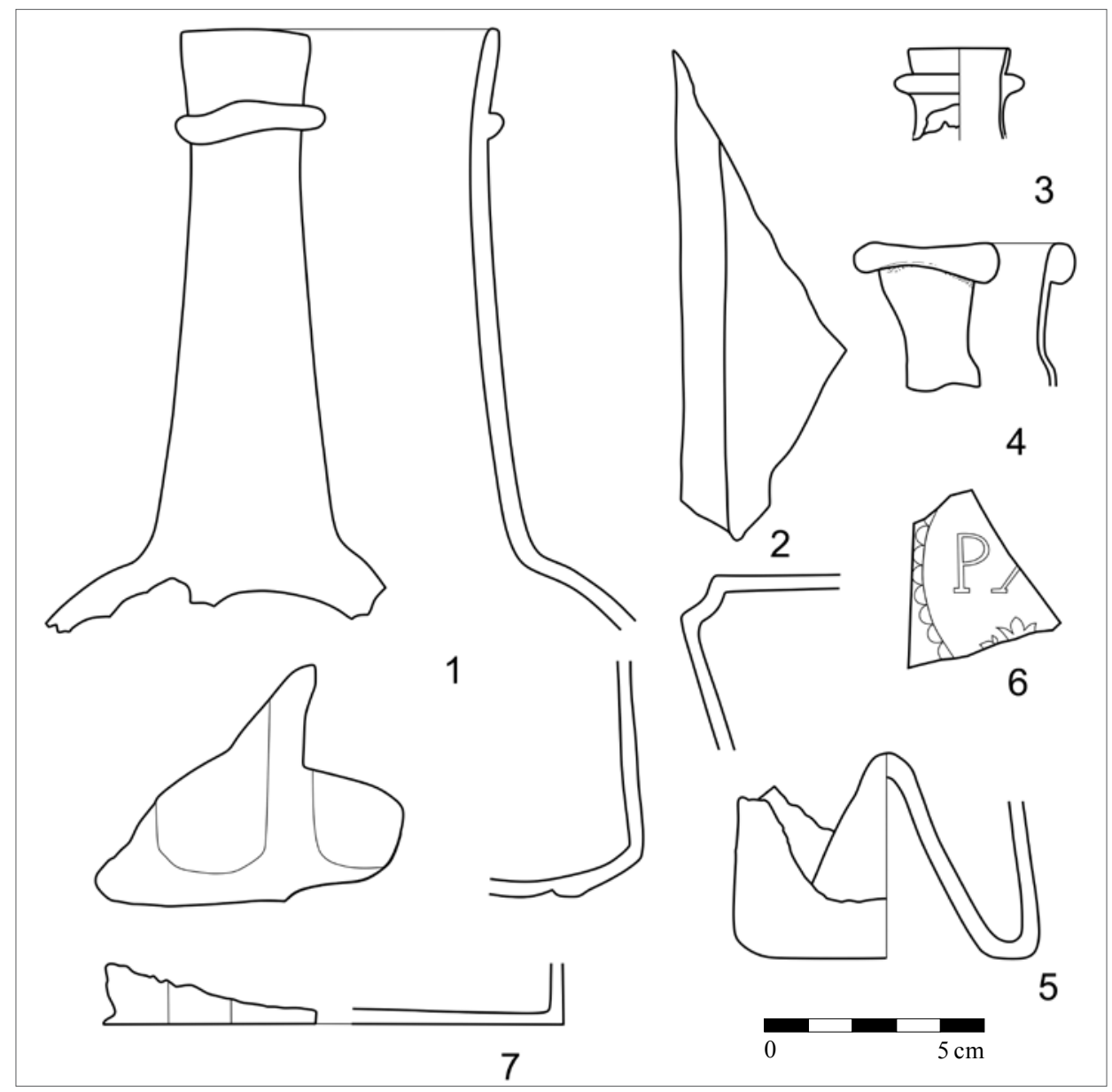

Tab. 3 Výběr skla. Kresba T. Kašparová.

Tab. 3 Auswahl an Glas. Zeichnung T. Kašparová.

Nalezené fragmenty skleněných nádob nevykazují další stopy rafinace, s výjimkou výše zmíněného nápisu a ještě dvou fragmentů broušené sklenice (či lahve) s hranovanými (fazetovanými) stěnami. Jeden ze střepů pochází ze dna nádoby (tab. 3:7), které bylo rovněž broušeno přepokládaný průměr sklenice či lahve je $7 \mathrm{~cm}$.

Jak bylo zmíněno v kapitole o dějinách kláštera, mniši nakupovali sklo ve sklárně na rožnovském panství. V druhé polovině 18 . století je v této doméně jenom jedna funkční sklárna, a to v dnešní obci Prostř̌ední Bečva v poloze V Huti (Španihel-Valoušková-Mašláň 2017, 152). Až na pár výše zmíněných výjimek můžeme tedy tuto sklárnu považovat za zdroj převážné většiny skleněných artefaktů ze Zašové.

\section{Soubor kostí}

V rámci pokusu o komplexní vyhodnocení nalezeného archeologického souboru jsme se pokusili interpretovat i nálezy osteologického charakteru. Bohužel vzhledem ke stavu kostí, 
které byly většinou neúplné, nebo se jednalo pouze o úlomky, jsme u některých nebyli schopni určit přímo druh, ale pouze čeled' nebo podčeled', př́ipadně skupinu zvířat. Některé kosti byly natolik poškozené, že nebylo možné zjistit typ kosti ani druh zviřrete. Z druhů zvírat se vyskytovali jelenovití (Cervidae), ovce nebo koza (Caprinae), prase (Sus sp.) a ptáci (Aves). Z kostí jsme identifikovali nejčastěji pažní kost (humerus), holenní kost (tibia), stehenní kost (femur), obratle (vertebrae) a prst (phalanx). Podrobněji jsou jednotlivé nálezy popsány v tabulce č. 4.

Díky popsaným kostem je možné nahlédnout do kuchyně místních mnichů a porovnat ji $\mathrm{s}$ výše zmíněným stravovacím plánem, který byl připraven $\mathrm{v}$ rámci šetření financí na dostavbu kláštera. Kromě běžných domácích zvířat zaujme zejména vysoký podíl lovné zvěře.

\begin{tabular}{|c|c|}
\hline TYP KOSTI & ZVÍŘĚ/DRUH \\
\hline \multicolumn{2}{|l|}{ SONDA S1 } \\
\hline Tibia sinistra dist. iuvenilis (tělo a distální část levé holenni kosti mladého zviřrete) & Cervidae \\
\hline Humerus sinister dist. iuvenilis (distální část levé pažni kosti mladého zvírete) & Cervidae \\
\hline Calcaneus (téměř celá patni kost $2 \times$ ) & Cervidae \\
\hline Phalanx proximalis (téměr celý proximální článek prstu) & Cervidae \\
\hline Os sesamoideum distalis (distálni sezamská kost) & Cervidae \\
\hline Proximální epifýza předloketní kosti & Cervidae \\
\hline Pelvis (část pánve) & Cervidae \\
\hline Calcaneus (celá patní kost) & Capreolus \\
\hline Femur sinister corpus (část těla levé stehenni kosti) & Sus sp. \\
\hline Humerus sinister (téměr celá levá pažni kost) & Sus sp. \\
\hline Pelvis (část pánve) & Sus sp. \\
\hline Tibia sinistra dist. (distální část levé holenní kosti) & Sus sp. \\
\hline Os sesamoidea (celá sezamská kost) & Bovidae \\
\hline $\begin{array}{l}\text { Tibia sinistra prox. iuvenilis (tělo a proximálni část levé holenni kosti mladého } \\
\text { zvírete) }\end{array}$ & Ovis \\
\hline Tibia sinistra prox. (proximální část holenni kosti) & Capra \\
\hline Vertebra lumbalis (část bederniho obratle) & Capra \\
\hline Costae (úlomky rủzných částí žeber) & Caprinae \\
\hline Femur dexter prox. + corpus (tělo a proximálni část pravé stehenni kosti) & Aves \\
\hline Femur sinister (celá levá stehenni kost) & Aves \\
\hline Radius sinister (celá levá vřetenni kost) & Aves \\
\hline Os centroquartale (celá srostlá střední a čtvrtá zánártni kost) & Ruminantia \\
\hline Tibia dextra dist. (distální část holenní kosti) & neurčeno \\
\hline Femur dexter dist. (distální část pravé stehenní kosti) & neurčeno \\
\hline Vertebra thoracica (část hrudního obratle $2 \times$ ) & neurčeno \\
\hline Humerus sinister dist. (distální část levé hrudní kosti) & neurčeno \\
\hline \multicolumn{2}{|l|}{ SONDA S2 } \\
\hline Vertebra caudalis $(1 \times$ téměr celý $+1 \times$ část ocasniho obratle $)$ & Cervidae \\
\hline Os sesamoideum prox. (proximální sezamská kost přední končetiny $2 \times$ ) & Cervidae \\
\hline Phalanx distalis sinister (levý distální článek prstu) & Cervidae \\
\hline Humerus dexter prox. (proximální část těla pažni kosti) & Sus sp. \\
\hline
\end{tabular}




\begin{tabular}{|c|c|}
\hline Tibia dextra prox. (proximální část holenní kosti) & Sus sp. \\
\hline Scapula sinistra dist. (distální část levé lopatky) & Ovís \\
\hline Costae (úlomky různých částí žeber) & Caprinae/cervidae \\
\hline Humerus dexter dist. $(1 \times$ tělo a distální část $+1 \times$ distální část pažní kosti) & Caprinae \\
\hline Atlas (část prvniho krčního obratle) & Capra \\
\hline Humerus dexter dist. $(1 \times$ tělo a distální část $+1 \times$ distální část pažní kosti) & Capra \\
\hline Tibiotarsus dist. (distální část holeně $2 \times$ ) & Aves \\
\hline Vertebra cervicalis (část krčního obratle) & neurčeno \\
\hline Vertebra thoracica (část hrudniho obratle) & neurčeno \\
\hline Tibia dextra dist. (distální část pravé holenní kosti $2 \times$ ) & neurčeno \\
\hline Calcaneus (část patni kosti) & neurčeno \\
\hline Phalanx proximalis dist. (distální část proximálního článku prstu) & neurčeno \\
\hline
\end{tabular}

Tab. 4. Rozbor určitelných kostí.

Tab. 4. Analyse der bestimmbaren Knochen.

\section{Závěr}

Zašovský klášter trinitářského řádu spolu s poutním kostelem a pramenem Stračka představuje unikátní materiální i symbolický komplex nejenom na Valašsku, ale i v jeho širším okolí. Architektonicky výrazná a hodnotná stavba vyniká v rurálním prostředí, kde s výjimkou domů na valašskomeziříčském náměstí, několika zámků a pár kostelů prakticky neexistují kamenné stavby.

Odlišnosti klášterního života od toho běžného světského dobře dokumentuje řádová materiální kultura doložená písemnými a materiálními prameny. Vznik odpadové jámy klademe do období závěrečné fáze existence kláštera, jeho zániku, nebo těsně po něm. Odpovídá tomu nejen nálezová situace, která dokládá vznik jámy až po druhém dláždění, a homogenní složení zásypu, ale i výše uvedená písemná zmínka o rozšiřrování a přestavbě rajského dvora v 60 . či 70 . letech 18. století, během kterého došlo pravděpodobně k předláždění (položení první dlažby předpokládáme v době první stavební etapy, tedy krátce po roce 1725). Pro podporu teorie o vzniku odpadové jámy až po zániku klášterní funkce objektu se můžeme obrátit i k postavení rajského dvora v symbolickém pojímání kláštera. Je málo pravděpodobné, že by na tak prestižním místě, které představuje onen nadpozemský ráj, existovala během jeho aktivního využívání dlouhodoběji funkční odpadová jáma. Samozřejmě je možné, že předláždění i následné vyhloubení jámy proběhlo s určitým odstupem po zániku kláštera, ale písemné prameny zde žádné další úpravy po zániku kláštera nezmiňují a jednotlivé předměty jsou vázány konkrétně na život místních mnichů. Nalezený archeologický soubor můžeme vzhledem k archeologické situaci a výše uvedeným analogiím datovat do druhé poloviny 18 . století.

Trinitářská komunita se ukázala nečekaně schopnou a i navzdory ne zrovna ideální finanční situaci nejenže byla s to rozvíjet místní poutní místo a budovat klášter, ale také se dokázala věnovat světským aktivitám, díky kterým se jistě mohla přiblížit místní populaci.

Krátký pobyt mnichů $\mathrm{v}$ Zašové je dodnes pozitivně vnímán jak v této obci, tak také $\mathrm{v}$ širším okolí. Samozřejmě je otázkou, jak by se jejich obraz a vliv měnil, kdyby jim bylo umožněno rozvíjet svou činnost více než pouhých 68 let. 


\section{Prameny}

HORÁKOVÁ, A., 2017: Motivy a symboly ve středověkých a barokních písních s mariánskou tematikou (A s čela se jí svezly na klekátko oříškové vlásky.) Nepublikovaná bakalářská práce, ulož. v Ústavu české literatury a knihovnictví FF MU, Brno.

KYNCL, T., 2018: Zašová, fara, čp. 44, dendrochronologie., Rkp. ulož. ve spisovém archivu NPÚ ÚOP v Kroměříži.

MATYÁŠ, J., 2011: Dějiny poutního kostela Navštívení Panny Marie v Zašové. Bakalářská práce, ulož. na Fakultě filozoficko-př́ŕrodovědecké SU, Opava.

- 2018: Zašová č. p. 45, bývalý trinitářský klášter. Historický průzkum. Rkp. ulož. v dokumentaci NPÚ ÚOP v Kroměříži.

MZA, B 2 G-Co: MZA, fond B 2 Gubernium - církevní oddělení, inv. č. 1437, sign. K 20/27a, kart. 81, spis č. $6496 / 1600$.

MZA, B 2 G-Co a: MZA, fond B 2 Gubernium - církevní oddělení, inv. č. 1437, sign. K 20/27b, kart. 82, spis č. $1509 / 207,1509 / 8225$.

MZA, E 65 TZ: MZA, fond E 65 Trinitáři Zašová, inv. č. 1019, sign. 2/2, kart. 1.

MZA, E 65 TZ a: MZA, fond E 65 Trinitáŕi Zašová, inv. č. 1031, sign. 11, kart. 1.

MZA, E 65 TZ b: MZA, fond E 65 Trinitáři Zašová, inv. č. 1046, sign. 23, kart. 2.

MZA, E 65 TZ c: MZA, fond E 65 Trinitáři Zašová, inv. č. 1048, sign. 25, kart. 2.

MZA, E 65 TZ d: MZA, fond E 65 Trinitáři Zašová, inv. č. 1058, sign. 33, kart. 2.

MZA, G 10 Sr: MZA, fond G 10 Sbírka rukopisů, kniha č. 77.

NA Praha, Čdk: Národní archiv Praha, fond Česká dvorská kanceláŕ, inv. č. 730, sign. IVb 101, kart. 401.

První vojenské mapování. Dostupné z: https://mapire.eu/en/map/europe-18century-firstsurvey, cit. 24. 11. 2018.

SOkA Vsetín, FúZ: MZA - Státní okresní archiv Vsetín, fond Farní úứad Zašová, inv. č. 23, sign. IVb.

ŠPANIHEL, S., 2016: Klášter sv. Jozefa v Zašové - rajský dvůr. Nepublikovaná nálezová správa z archeologického výzkumu, ulož. v Muzeu regionu Valašsko, Vsetín.

ŠIMČÍK, J.-ŽUREK, J., 2016: Bývalý Ústav sociální péče Zašová. Zaměření stávajícího stavu objektu č. p. 45. Nepublikováno.

ŠPANIHEL, S.-ZBRANKOVÁ, T., 2017: Klášter sv. Jozefa v Zašové - rajský dvůr (druhá etapa). Nepublikovaná nálezová správa z archeologického výzkumu, ulož. v Muzeu regionu Valašsko, Vsetín.

ŠTĚTINA, J.-VRLA, R., 2017: Zašová č. p. 45, bývalý trinitářský klášter, Stavebně-historický průzkum. Národní památkový ústav, územní odborné pracoviště v Kroměříži, rkp., 103 s., Kroměříž, ulož. ve spisovém archivu NPÚ ÚOP v Kroměříži.

\section{Literatura}

BALETKA, T., 2002: Zašová. In: Okres Vsetín: Rožnovsko - Valašskomeziříčsko - Vsetínsko (Nekuda, V., ed.), 915-918. Brno.

BAYER, A., 1904: O památnostech poutního místa Zašové. Moravská Ostrava.

BUBEN, M. M., 2007: Encyklopedie řádů, kongregací a řeholních společností katolické církve v českých zemích. Žebravé řády III/2. Praha.

BURIAN, B., 1941: Zašovský rektor Jan Vranečka. In: Naše Valašsko. Sborník prací o jeho životě a potřebách, 118-130. Valašské Meziřričí.

ČERNOHORSKÝ, K., 1932: Př́íspěvek k dějinám fajánsové výroby ve Val. Meziříčí, Naše Valašsko 3, $53-66$

- 1941: Jan Vranečka, první valašský tufar, Naše Valašsko 7, 60-63.

- 1941a: Moravská lidová keramika. Praha.

DEMEK, J.-NOVÁK, V., 1992: Vlastivěda Moravská. Země a lid. Brno.

DOMLUVIL, E., 1914: Vlastivěda moravská. Val-Meziř́čský okres. Brno.

FOLTÝN, D. a kol., 2005: Encyklopedie moravských a slezských klášterů. Praha.

HRBKOVÁ, R., 1974: Moravská lidová keramika 1700-1880. Praha.

PAJER, J., 1983: Počátky novověké keramiky ve Strážnici. Strážnice.

- 2006: Studie o Novokřtěncích. Strážnice.

- 2011: Novokřtěnecké fajánse z Moravy 1593-1620. Strážnice. 
SAMUEL, M.-ČURNÝ, M., 2012: Pottery from the cellar of a monastic dwelling at the Kamaldul monastery in Nitra-Zobor - Keramika z pivnice mníšskeho príbytku kamaldulského kláštora v Nitre na Zobore, Studies in Post-Medieval Archaeology 4, 429-452.

SVÁTEK, J., 1990: Trinitáři a jejich rezidence v Holešově. In: Studie Muzea Kroměřížska, 103-116. Kroměříž.

ŠIGUT, F., 1942: Poutní místo Zašová. Valašské Meziříčí.

ŠPANIHEL, S., 2014: Stredoveká a novoveká keramika severozápadného Slovenska, ŠZ AÚ SAV 55, $141-179$.

- 2016: Nálezy keramiky z pevnosti v Čiernom-Valoch. Keramikfunde aus der Festung in Čierne-Valy, ZbSNM CX - Archeológia 26, 151-161.

- 2017: Keramika a jej možnosti pri periodizácii raného novoveku na Slovensku, Pravěk NŘ 25, 293-314.

ŠPANIHEL, S.-VALOUŠKOVÁ, K.-MAŠLÁŇ, P., 2017: Lesní sklárny na Valašsku - I. etapa - Forest glassworks in Moravian Wallachia - 1st stage, Sklář a keramik 07-08, 148-153, 163.

ŠTAJNOCHR, V., 2006: Mísy. Studia funkcí novověké keramiky, ASČ 10, 959-1046.

ŠUJAN, V., 1982: Moravské lidové fajánse. Brno.

URBACHOVÁ, E., 1986: Fajáns ve sbírkách OVM Vsetín - pracoviště ve Valašském Meziříč́í, Zpravodaj Okresního vlastivědného muzea ve Vsetíně, 15-19.

\section{Zusammenfassung}

\section{Kloster des Trinitarierordens zum Loskauf christlicher Sklaven in Zašová (Zaschau)}

Das Kloster wurde in der Gemeinde Zaschau wegen der Verwaltung der Wallfahrtskirche sowie im Rahmen der Bemühungen gegründet, geheime Protestanten zu rekatholisieren, die sich auch im 18. Jahrhundert in der Mährischen Walachei versteckt hielten. Der Grundstein des Trinitarierklosters wurde am 4. Oktober 1725 gelegt, und der Bau wurde während der ganzen Existenz des Klosters fortgesetzt. Die Mönche widmeten sich außer ihrer Rekatholisierungsmission und der Verwaltung der Kirche auch Ordensaufgaben, d.h. der Organisation von Geldsammlungen für den Loskauf von Sklaven. Es ermangelte ihnen auch nicht in praktischer Hinsicht, sie brachten mehrere landwirtschaftliche Inventionen in die Mährische Walachei und beschäftigten sich auch mit Wissenschaft. Ihre Erfolge wurden 1783 bereits zunichte gemacht, als Kaiser Joseph II. das Kloster im Rahmen seiner Reformen auflöste.

Das Kloster selbst bestand aus einem langen einstöckigen und in ganzer Länge unterkellerten Ostflügel und dem gegenüberliegenden kürzeren einstöckigen und nicht unterkellerten Westflügel. Beide Flügel verband ein ebenfalls einstöckiger, teilweise unterkellerter Querflügel, der unter anderem auch die zweiläufige Haupttreppe enthielt. Der kleine Hof (Paradieshof) hatte einen quadratischen Grundriss, der von einem im Innern gewölbten Erdgeschosskreuzgang umschlossen wurde. Im Süden schloss die ausgedehnte Klosterkirche an das Klostergebäude an. Das Kloster wurde nie zu Ende gebaut, es fehlen die nördliche Hälfte des Westflügels und der ganze Nordflügel, der den zweiten, nördlichen Hof offenbar abschließen sollte.

Die archäologische Grabung konzentrierte sich auf den Paradieshof, in dem drei Sondierschnitte ausgehoben wurden. Alle Sondierschnitte boten das gleiche Grundbild - der Hof war zweimal mit einer einfachen Pflasterung umgepflastert worden. Die ältere Pflasterung wurde qualitativ hochwertig mit Bruchsteinen ausgeführt, die jüngere hatte einen einfacheren Aufbau und bestand aus Flussfindlingen. Dank den einzelnen Sondierschnitten wurde festgestellt, dass der Hof auf dem Niveau der ersten Pflasterung komplizierter gegliedert war. Der Brunnen hatte eine stufenartige Baukonstruktion, und zum Osteingang führten Treppen. Wahrscheinlich wurde gleich nach Untergang des Klosters im Hof in der neuen Pflasterung eine Grube ausgehoben, die wohl mit Küchenabfällen gefüllt wurde. Der Fundkomplex bestand aus Keramik, Glas und Knochen. Die Küchen - und Tafelkeramik bestand aus glasierter Irdenware und Fayancen, die wahrscheinlich aus Valašské-Meziříčí stammte. Glas war besonders durch Hohlgefäße vertreten, die in der Küche, bei Tisch sowie in der Pharmazie dienten. Die Analyse der Knochen hat gezeigt, dass außer den üblichen Wirtschaftstieren auch Rotwild auf den Klostertisch kam. 
Das Kloster des Trinitarierordens stellte in der ländlichen Region der Mährischen Walachei einen einzigartigen materiellen und ideellen Komplex dar. Der Bau selbst, die fortschrittlichen Aktivitäten der Ordensbrüder und ihre materielle Kultur haben auf die lokale Bevölkerung in einem barocken Geiste gewirkt und auch trotz ihrer kurzen Tätigkeit nicht nur in Zašová bis heute ein lebendiges Vermächtnis hinterlassen.

Mgr. Samuel Španihel, Muzeum regionu Valašsko, p. o., Horní náměstí 2, 75500 Vsetín, Česká republika, spanihel@muzeumvalassko.cz

Mgr. Jan Matyášs, Národní památkový ústav, územní odborné pracoviště v Kroměřǐži, Riegrovo náměstí 3228/22, 76701 Kroměříž, Česká republika, matyas.jan@npu.cz

Mgr. Jan Štetina, Národní památkový ústav, územní odborné pracoviště v Kroměřǐži, Riegrovo náměstí 3228/22, 76701 Kroměříž, Česká republika, stetina.jan@npu.cz

Mgr. Kamila Valoušková, Muzeum regionu Valašsko, p. o., Horní náměstí 2, 75500 Vsetín, Česká republika,valouskova@muzeumvalassko.cz

doc. Dr. Ing. Zdeněk Havlíček, Ústav morfologie, fyziologie a genetiky zvířat Mendelovy univerzity v Brně, Zemědělská 1, 61300 Brno, Česká republika, zdenek.havlicek@mendelu.cz

Ing. Lucie Langová, Ústav morfologie, fyziologie a genetiky zvírat Mendelovy univerzity v Brně, Zemědělská1,61300 Brno, Česká republika, xlangov2@node.mendelu.cz

Ing. Ivana Novotná, Ústav morfologie, fyziologie a genetiky zvířat Mendelovy univerzity v Brně, Zemědělská 1, 61300 Brno, Česká republika, xvafkova@ node.mendelu.cz 
